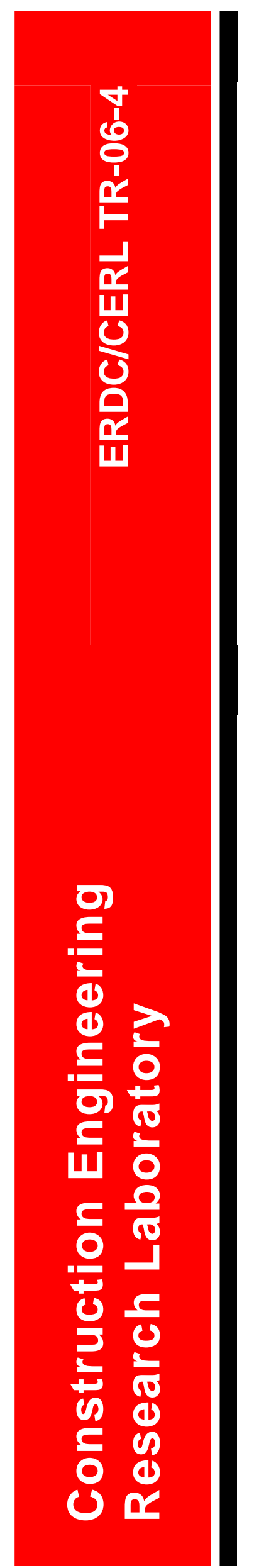

\title{
Effect of Age-dependent Forest Characteristics on Acoustic Propagation
}

Michelle E. Swearingen

March 2006

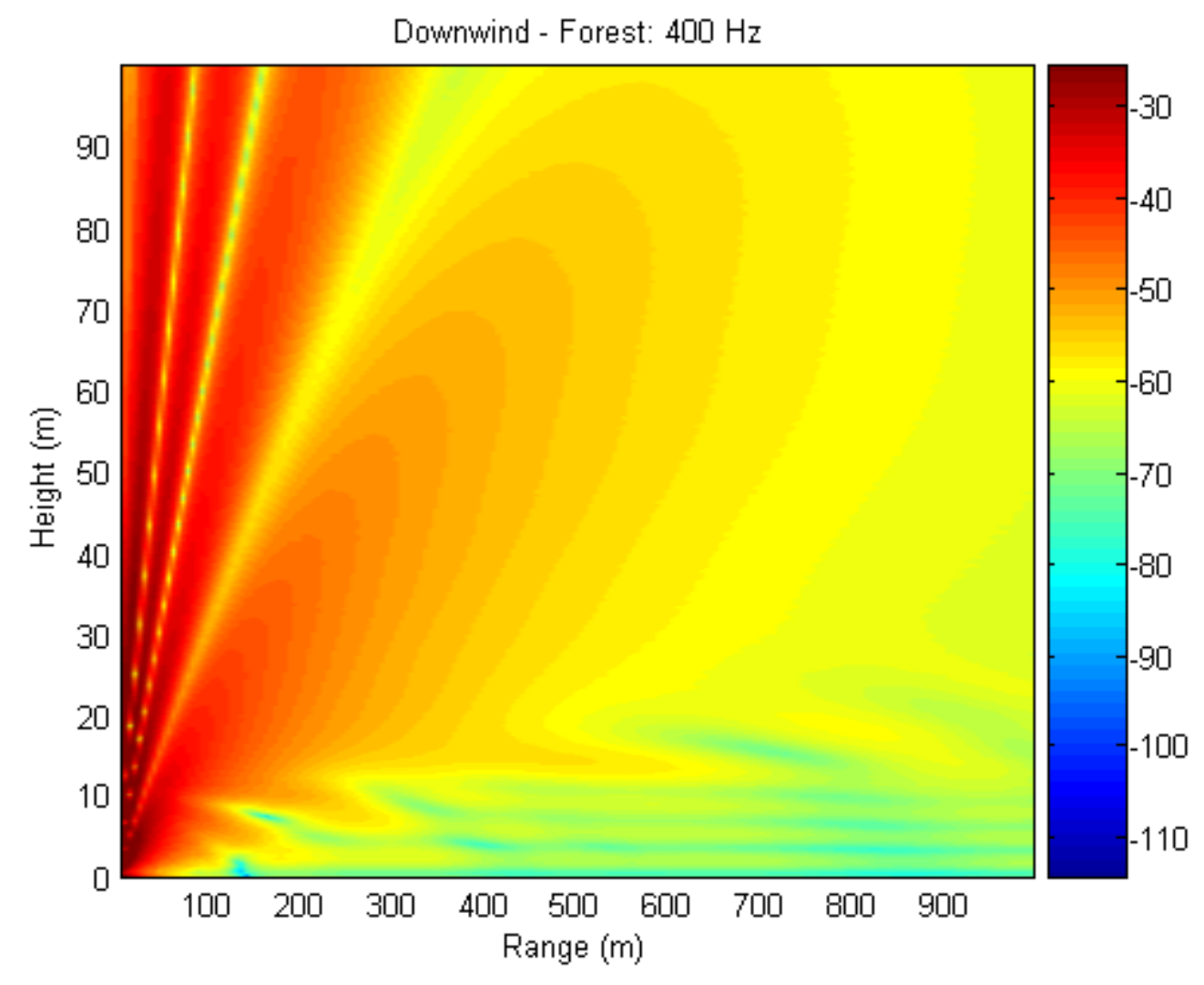




\section{Effect of Age-dependent Forest Characteristics on Acoustic Propagation}

Michelle E. Swearingen

U.S. Army Engineer Research and Development Center

Construction Engineering Research Laboratory

PO Box 9005

Champaign, IL 61826-9005

Final Report

Approved for public release; distribution is unlimited.

Prepared for U.S. Army Corps of Engineers

Washington, DC 20314-1000

Under

Work Unit \#3JD946 
ABSTRACT: This report contains the results of a theoretical study on the impact of forest stand age on acoustic propagation. A red pine forest was simulated at 10, 20, 30, 40, and 80 years of age, with assumptions that it was being maintained for utility pole harvest. Forest parameters, such as density, height, and diameter of trees, were used to predict vertical sound speed profiles and then acoustic propagation. The resulting spectra were weighted to simulate artillery and rifle fire. Spectra and sound exposure levels were examined to determine whether the forest stand age has a significant impact on acoustic propagation within a forest.

Cover: Summer day, 40-year forest, downwind condition. Colors represent transmission loss in decibels.

DISCLAIMER: The contents of this report are not to be used for advertising, publication, or promotional purposes. Citation of trade names does not constitute an official endorsement or approval of the use of such commercial products. All product names and trademarks cited are the property of their respective owners. The findings of this report are not to be construed as an official Department of the Army position unless so designated by other authorized documents.

DESTROY THIS REPORT WHEN IT IS NO LONGER NEEDED. DO NOT RETURN IT TO THE ORIGINATOR. 


\section{Contents}

List of Figures and Tables ..................................................................................................... iv

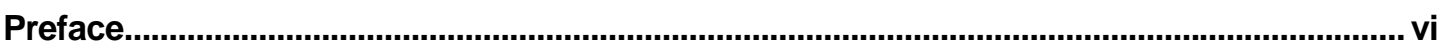

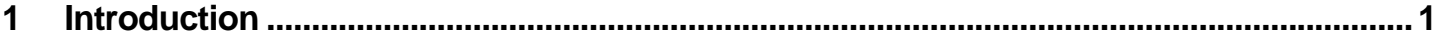

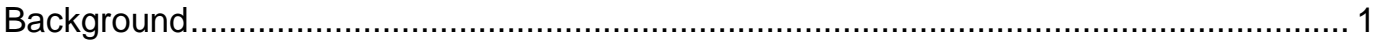

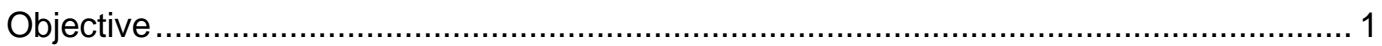

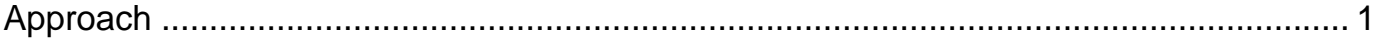

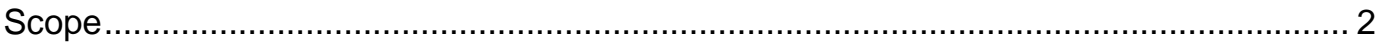

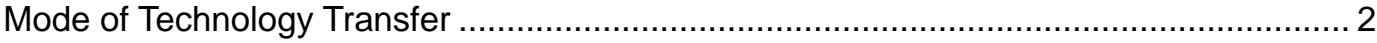

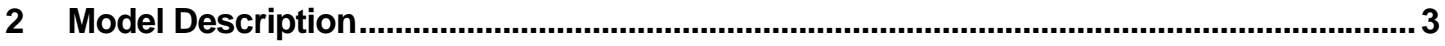

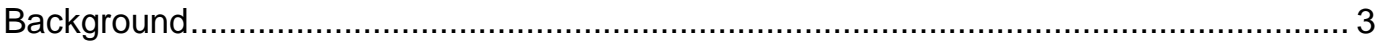

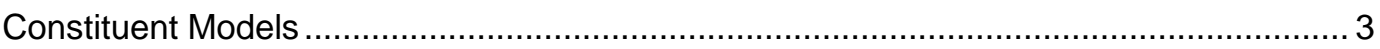

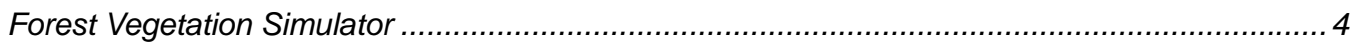

One-Dimensional Meteorology Model ................................................................... 5

Forest Green's Function Parabolic Equation ................................................................... 6

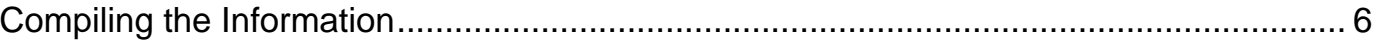

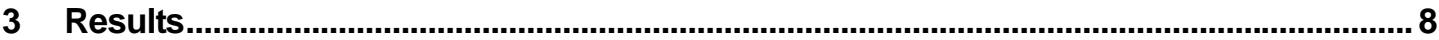

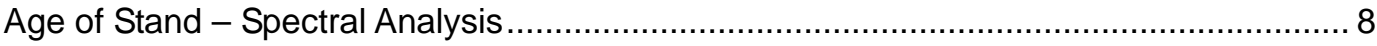

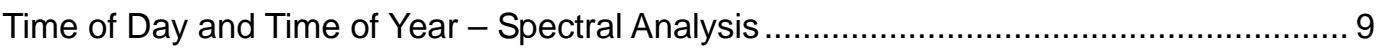

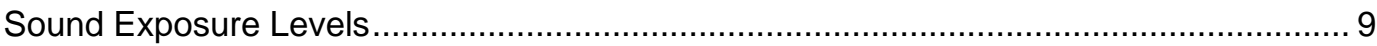

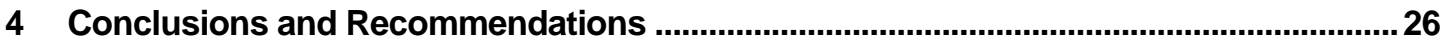

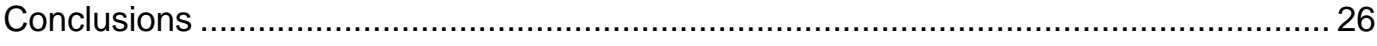

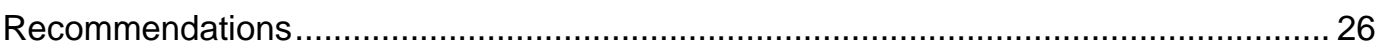

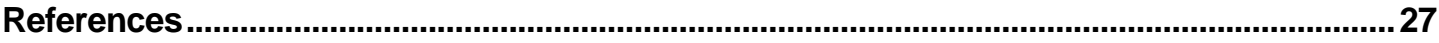

Appendix: Sound Propagation Modeling Results for Slash Pine Data................................28

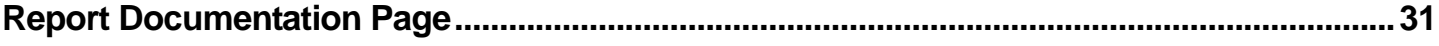




\section{List of Figures and Tables}

\section{Figures}

1 Factorial representation of the set of cases examined in this study .... 6

2 Summer Daytime downwind cases, all forest stand ages, transmission loss of unweighted levels.

3 Summer Nighttime downwind cases, all forest stand ages, transmission loss of unweighted levels.

$4 \quad$ Winter Daytime downwind cases, all forest stand ages, transmission loss of unweighted levels.

5 Winter Nighttime downwind cases, all forest stand ages, transmission loss of unweighted levels.

6 Summer Daytime downwind case, difference in transmission loss between 10year stand and all other ages.

7 Summer Nighttime downwind case, difference in transmission loss between 10-year stand and all other ages

8 Winter Daytime downwind case, difference in transmission loss between 10year stand and all other ages.

$9 \quad$ Winter Nighttime downwind case, difference in transmission loss between 10year stand and all other ages

10 Spectra weighted with $1.25 \mathrm{lb}$ C4 spectrum. Summer Daytime case, all stand ages......

11 Spectra weighted with rifle spectrum. Summer Nighttime case, all stand ages ...... 20

12 Unweighted spectrum of 10-year red pine stand for all temporal conditions, downwind case.

13 Unweighted spectrum of 20-year red pine stand for all temporal conditions, downwind case

14 Unweighted spectrum of 30-year red pine stand for all temporal conditions, downwind case

15 Unweighted spectrum of 40-year red pine stand for all temporal conditions, downwind case.

16 Unweighted spectrum of 80-year red pine stand for all temporal conditions, downwind case.

A1 Calculated spectrum weighted with $1.25 \mathrm{lb}$ Composition C4 signature, slash pine forest...... 


\section{Tables}

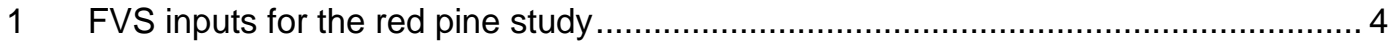

2 Output from FVS in red pine study and estimated canopy parameters ..................... 4

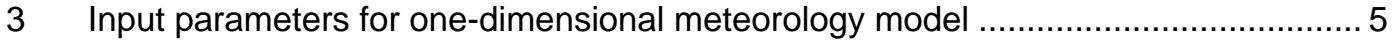

4 Stand age-specific input parameters for the one-dimensional meteorology

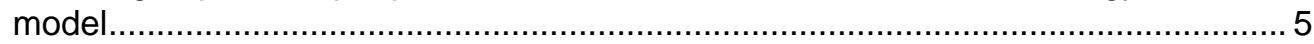

5 Predicted received levels from $1.25 \mathrm{lb} \mathrm{C4}$ for the downwind condition, at

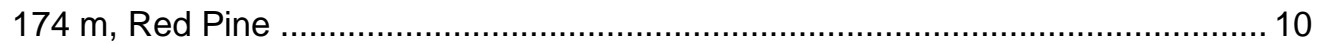

$6 \quad$ Predicted received levels from $1.25 \mathrm{lb} \mathrm{C4}$ for the downwind condition, at

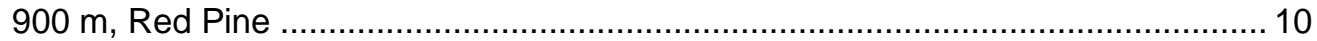

7 Predicted received levels from rifle shot for the downwind condition, at $174 \mathrm{~m}$, Red Pine. 10

8 Predicted received levels from rifle shot for the downwind condition, at $900 \mathrm{~m}$, Red Pine. 


\section{Preface}

This study was conducted for U.S. Army Corps of Engineers as part of the Training and Testing Noise Control Environmental Quality Technology Program under Project 622720D048, "Industrial Operations and Pollution Control Technology," work unit 3JD946 "Noise Mitigation by Forests." The technical monitor was William Russell, U.S. Army Center for Health Promotion and Preventive Medicine.

The work was performed by the Ecological Processes Branch (CN-N) of the Installations Division (CN), Construction Engineering Research Laboratory (CERL). The CERL Principal Investigator was Michelle E. Swearingen. The technical editor was Linda L. Goersch, Information Technology Laboratory. Alan Anderson is Chief, CNN, and Dr. John T. Bandy is Chief, CN. The associated Technical Director was Dr. William Severinghaus. The Acting Director of CERL is Dr. Ilker Adiguzel.

The author gratefully acknowledges the contributions of four individuals during the course of this project. Tom Vorac, U.S. Army Environmental Center, provided the initial idea of "growing" a forest to look at changes in acoustic propagation over time. He provided the growth estimates used in the initial study described in the Appendix. Patrick Guertin, CERL, learned and ran the Forest Vegetation Simulator for the main part of the project and provided estimates for canopy thickness and closure. Arnold Tunick, Army Research Laboratory, provided the vertical sound speed profiles based on forest structural parameters, time of year, time of day, and location. Dr. Michael White, CERL, assisted in designing the theoretical study and narrowing down the number of cases to something reasonable. Without the assistance of so many, this project would not have been possible.

CERL is an element of the U.S. Army Engineer Research and Development Center (ERDC), U.S. Army Corps of Engineers. The Commander and Executive Director of ERDC is COL James R. Rowan, and the Director of ERDC is Dr. James R. Houston. 


\section{Introduction}

\section{Background}

For several years, the U.S. Army has been experimenting with different techniques and media for low-frequency noise mitigation. Typical noise mitigation techniques depend heavily on the relationship of size to relevant wavelength. This poses a unique challenge for low-frequency training noise, such as from demolitions, artillery, and armor, which have large amounts of energy in the 30-50 hertz $(\mathrm{Hz})$ range, corresponding to wavelengths on the order of 10 meters $(\mathrm{m})$.

One promising mitigation medium is a forest. Previous work has indicated that a forest has some effect on low-frequency noise, but it is frequency-dependent (Swearingen and White 2004). Low frequencies are expected to be largely influenced by refraction induced by the microclimate. In turn, the microclimate is assumed to be dependent upon the composition of the forest. Because a forest is a dynamic environment, it is necessary to look at changes as the forest grows and at different times of the year.

\section{Objective}

The study's objective is to determine whether the physical age-dependent characteristics of a forest have an impact on potential noise mitigation benefits for military training and testing noise and, if so, to gain an understanding of the effects. Understanding will allow the Army to wisely manage its training facilities.

This project concentrates primarily on one particular type of forest; namely, stands typical of the North-Central United States that are composed principally of red pine species. The results of this project are thought to be valid for this forest type and location, and may be only indicative for other types of forest (e.g., deciduous forests).

\section{Approach}

This project used three distinct models in concert with one another to learn how changes in forest characteristics (e.g., trunk diameter, tree height, and number of 
trees per unit area) impact acoustic propagation through a forest. The first step was to use a growth simulator, Forest Vegetation Simulator (FVS) to age and perform forest management practices on a theoretical stand of red pine. The theoretical forest was managed as if it were being maintained for utility pole production. Snapshots in time were taken at 10, 20, 30, 40, and 80 years of age. Information provided by the FVS included average tree height, average diameter at breast height (DBH), and number of trees per acre. Canopy thickness and canopy closure were estimated based on red pine characteristics. Information about the physical structure of the forest at these ages was then entered into a forest microclimate vertical sound speed and wind speed profile algorithm (Tunick 2003). The vertical sound speed profiles were combined with the vertical wind speed profiles to create "effective" sound speed profiles for upwind and downwind cases. These effective sound speed profiles, along with the physical forest parameters, were then utilized by the Forest Green Function Parabolic Equation (GFPE; Swearingen and White 2004).

\section{Scope}

This report contains the results of analytical modeling and a discussion of implications for military training and testing noise mitigation. It provides guidance for forestry and training managers regarding the efficacy of one particular type of forest for attenuation of noise levels in the surrounding community. The results presented in this report are tailored to a forest stand of red pine in the North Central United States and are applicable to other forest types and locations only in a general fashion.

\section{Mode of Technology Transfer}

This report will be provided to the Operational Noise Program of the U.S. Army Center for Health Promotion and Preventive Medicine (USACHPPM), the Army technical transfer agent for and primary user of military blast noise technology, and to other known users. This report will be made accessible through the World Wide Web (WWW) at URL: http://www.cecer.army.mil 


\section{Model Description}

\section{Background}

For several years the U.S. Army Engineer Research and Development Center (ERDC) has been investigating the feasibility of using forests to mitigate blast noise. To date these investigations have included a series of experimental measurements and the development of a sound propagation algorithm that accounts for forest characteristics. This report describes an analytic exercise that was designed to study the potential changes in sound propagation characteristics as a stand of trees ages. This exercise starts with a 10-year-old red pine stand in the NorthCentral United States. This stand is grown for 80 years and maintained with utility poles as the desired product.

As part of a previous CERL study (see appendix), a more preliminary version of the current study was performed. In this preliminary case, a slash pine forest in the South-Central United States from its initial state and was grown for 20 years using rough growth percentages. Additionally, the initial state was thinned to 40 percent of its original trees and then grown for 20 years. This preliminary study enabled the researchers to gain some insight into whether thinning a forest had an impact on sound propagation in the short term (immediately), the long term (20 years), or both. It was found that, in the short term, thinning the trees resulted in slightly less attenuation in the higher frequencies (above $200 \mathrm{~Hz}$ ). After 20 years of growth, the initial state provided more attenuation than the thinned state but, again, for the higher frequencies. From a sound exposure standpoint, however, change was negligible with either time or thinning when the calculated spectra were frequencyweighted by the source spectrum of a $1.25 \mathrm{lb}(0.567 \mathrm{~kg})$ charge of $\mathrm{C} 4$ plastic explosive. This result is likely due to the relatively large amount of energy in lower frequencies contained in the blast wave. For additional information on this preliminary study, see the appendix.

\section{Constituent Models}

As stated in chapter 1, this effort included the use of three distinct modeling algorithms. The first was the FVS model, used for predicting forest growth and structure statistics. The second was a one-dimensional meteorological model, used for 
predicting vertical sound and wind speed profiles. The third was an acoustic propagation algorithm that takes forest structural parameters and vertical sound and wind speed profiles into account. More detailed descriptions of each model follow.

\section{Forest Vegetation Simulator}

The forest growth model FVS has existed since 1973. The U.S. Department of Agriculture (USDA) Forest Service maintains and supports this application. FVS may be run within the Land Management System (LMS) suite of tools, and is presented as one of two choices of forest growth models in LMS. Additional information regarding LMS is available at http://lms.cfr.washington.edu/. Additional information regarding FVS is available at http://www.fs.fed.us/fmsc/fvs/.

The FVS was chosen for this study because of its accurate, multi-parameter growth model. This growth model takes location, soil type, tree mortality, and tree type into account. For example, trees in poor soil will not grow as quickly and their mortality rate will be higher, but trees in excellent soil will grow more quickly with a lesser mortality rate. This model also allows the user to decide what the intended forest product will be and has algorithms that will incorporate the proper forest management practices for that desired product. Table 1 lists inputs to the FVS for the red pine study. Table 2 lists relevant output information.

Table 1. FVS inputs for the red pine study.

\begin{tabular}{|l|l|}
\hline Site Index (SI) & 65 \\
\hline Region & Chippewa National Forest \\
\hline Tree Species & Red pine \\
\hline Initial Planting Density & $\begin{array}{l}6 \mathrm{ft} \times 8 \mathrm{ft} \text { with } 20 \% \text { mortality in } 1^{\text {st }} 10 \\
\text { years }\end{array}$ \\
\hline $1^{\text {st }}$ Thinning & At 35 years, every third row removed \\
\hline $2^{\text {nd }}$ Thinning & At 45 years, thin to Basal Area of 140 \\
\hline $3^{\text {rd }}$ Thinning & At 55 years, thin to Basal Area of 100 \\
\hline Intended Forest Product & Utility poles \\
\hline
\end{tabular}

Table 2. Output from FVS in red pine study and estimated canopy parameters.

\begin{tabular}{|c|c|c|c|c|c|}
\hline $\begin{array}{c}\text { Age } \\
(\mathbf{y r})\end{array}$ & TPA* $^{*}$ & $\begin{array}{c}\text { DBH**}^{* *} \\
\mathbf{( m )}\end{array}$ & $\begin{array}{c}\text { Tree } \\
\text { Height }(\mathbf{m})\end{array}$ & $\begin{array}{c}\text { Canopy Closure } \\
(\mathbf{\%}), \text { est. }\end{array}$ & $\begin{array}{c}\text { Crown Height } \\
(\mathbf{m}), \text { est. }\end{array}$ \\
\hline 10 & 726 & 0.025 & 2.15 & 70 & 1.0 \\
\hline 20 & 726 & 0.104 & 4.9 & 60 & 3.4 \\
\hline 30 & 657 & 0.173 & 9.2 & 55 & 7.8 \\
\hline 40 & 370 & 0.226 & 11.7 & 50 & 9.8 \\
\hline 80 & 128 & 0.391 & 16.9 & 40 & 12.9 \\
\hline
\end{tabular}

* Trees per acre.

**Diameter at breast height. 


\section{One-Dimensional Meteorology Model}

The meteorological prediction model was developed and provided by Tunick (2003) at the Army Research Laboratory (ARL). This model uses a series of inputs based on the forest structure, location, time of day, time of year, and general meteorological conditions to predict vertical sound and wind speed profiles in and above a forest. Tables 3 and 4 list parameters used to generate the sound speed profiles. In each calculation, the maximum height of calculation $(30 \mathrm{~m})$ was held constant, which produced small instabilities in the calculations in some cases, causing higher than expected wind values at higher altitudes. These instabilities led to stronger downward refraction for the younger (and shorter) forest cases, resulting in less transmission loss. The instabilities affect the 10-year and 20-year stand vertical wind profiles.

Table 3. Input parameters for one-dimensional meteorology model.*

\begin{tabular}{|l|l|}
\hline Cloud Amount & 0.2 \\
\hline Cloud Base & $1000 \mathrm{ft}$ \\
\hline Latitude & 46.08 \\
\hline Longitude & $94.35 \mathrm{~W}$ \\
\hline Julian Day & 205 (summer) and 15 (winter) \\
\hline Local Time & 1300 (day) and 0100 (night) \\
\hline Max wind at 3h & $4.8 \mathrm{~m} / \mathrm{s}$ \\
\hline Canopy Top Temperature & $35.0 \mathrm{C}$ (summer), 5.0 C (winter) \\
\hline Relative Humidity & $50 \%$ \\
\hline Surface Pressure & $1019 \mathrm{mbar}$ \\
\hline Leaf area Profile & Crown is sparse and oval \\
\hline Average Leaf size & $5 \mathrm{~mm} \times 155 \mathrm{~mm}$ \\
\hline Drag coefficient & $0.1-0.2$ \\
\hline Tree Type & Red Pine \\
\hline
\end{tabular}

*These parameters are constant across all cases except where indicated.

Table 4. Stand age-specific input parameters for the onedimensional meteorology model.

\begin{tabular}{|c|c|c|c|}
\hline $\begin{array}{c}\text { Age } \\
(\mathbf{y r})\end{array}$ & $\begin{array}{c}\text { Canopy Height } \\
(\mathbf{m})\end{array}$ & $\begin{array}{c}\text { Canopy Closure } \\
(\mathbf{\%})\end{array}$ & $\begin{array}{c}\text { Crown Height } \\
(\mathbf{m})\end{array}$ \\
\hline 10 & 2.15 & 70 & 1.0 \\
\hline 20 & 4.9 & 60 & 3.4 \\
\hline 30 & 9.2 & 55 & 7.8 \\
\hline 40 & 11.7 & 50 & 9.8 \\
\hline 80 & 16.9 & 40 & 12.9 \\
\hline
\end{tabular}




\section{Forest Green's Function Parabolic Equation}

The Forest GFPE model was developed in 2004 as part of the ongoing forest acoustics research effort. This model incorporates a vertical sound speed profile, realistic complex acoustic ground impedance, and scattering from trunks and large limbs. It calculates single frequency acoustic propagation in two dimensions, horizontal and vertical, and assumes one-way propagation away from the source. White and Swearingen (2004) give a detailed description of this model.

It should be noted that the Forest GFPE is based on Twersky's scattering model (Twersky 1962). It predicts the coherent forward propagation but subtracts the scattered incoherent energy from the total field. The incoherent energy propagates in all directions and is heard as a reverberant time signal.

\section{Compiling the Information}

Once all of the information was available, the Forest GFPE was used to examine differences in acoustic propagation with time of year, time of day, and forest stand age. The average trunk diameters, canopy and crown heights, and density of trees are all age-dependent. All these factors contribute to changes in the microclimate with age.

Forty cases were examined in this project. Figure 1 illustrates the factorial representation.

$$
\left(\begin{array}{c}
\text { Night } \\
\text { Day }
\end{array}\right) \times\left(\begin{array}{c}
\text { Summer } \\
\text { Winter }
\end{array}\right) \times\left(\begin{array}{c}
\text { Upwind } \\
\text { Downwind }
\end{array}\right) \times\left(\begin{array}{c}
10 \text { years } \\
20 \text { years } \\
30 \text { years } \\
40 \text { years } \\
80 \text { years }
\end{array}\right)=40 \text { Cases }
$$

Figure 1. Factorial representation of the set of cases examined in this study.

The combination of cases shown in Figure 1 allowed for the examination of the propagation through a forest for a variety of tree stand ages, time of year, and time of day.

Special note: Upwind cases were calculated in this study; however, they will not be examined in this report. Significant shadow zone effects were seen in the calculated transmission loss, causing the frequency range from about 200-1400 $\mathrm{Hz}$ to show extremely low levels both near $(174 \mathrm{~m})$ and far $(900 \mathrm{~m})$. In a natural 
setting, turbulence and reverberant scattering significantly lessen the impact of the shadow zone, so it is maintained that the upwind case results are not physically possible (Daigle 1978). 


\section{Results}

The resulting predictions of transmission loss were comparatively analyzed in several different ways. One way was to look at transmission loss of white noise, which has equal spectral energy density at each frequency. Additionally, the calculated spectra were weighted with a $1.25 \mathrm{lb}(0.567 \mathrm{~kg})$ Composition C4 Friedlander source spectrum (Friedlander 1946) (maximum energy $\sim 40 \mathrm{~Hz}$ ) to simulate large weapon fire and $0.0001 \mathrm{lb}(4.54 \mathrm{mg}) \mathrm{C} 4$ Friedlander source spectrum (maximum energy around $500 \mathrm{~Hz}$ ) to simulate a rifle shot. Additionally, sound exposure levels (SELs) were calculated for the large weapon and rifle shot weighted cases. Because the goal of this study was to determine whether there are differences in propagation based on forest structure, time of day, and time of year, the calculated spectra are not compared to open field cases.

\section{Age of Stand - Spectral Analysis}

Comparisons in acoustic propagation with regards to stand age were performed two different ways: as spectral transmission loss curves plotted on the same graph, and as the change in transmission loss relative to a 10-year stand. Additionally, the spectra are weighted with $1.25 \mathrm{lb} \mathrm{C} 4$ and a rifle shot spectrum. Received levels are plotted in decibels $(\mathrm{dB})$.

Figures $2-5^{*}$ show the transmission loss spectra according to time of day and time of year. All five stand ages are included on each plot. These plots show significant variation with stand age in received spectra for the unweighted cases. It may be noted that, in some cases, the 40-year stand provides more transmission loss (attenuation) than the 80 -year stand. This difference is likely due to the significant thinnings that were performed at 45 and 55 years. The reduced number of trees can reduce the overall loss due to scattering since there are fewer "hits" (smaller scattering cross-sectional area) to redirect and attenuate the sound.

\footnotetext{
* Figures 2 through 16 are shown at the end of the chapter, beginning on page 11.
} 
The differences in transmission loss are much clearer in Figures 6-9. In this set of plots, the 20-, 30-, 40-, and 80-year stand spectra are subtracted from the 10-year stand spectra for a given temporal situation (e.g., summer day). In these plots, a positive number indicates larger transmission loss than the 10-year case (desirable for noise mitigation); a negative number indicates less transmission loss than the 10-year case (undesirable for noise mitigation). In the unweighted case, low frequency effects of up to $5 \mathrm{~dB}$ at $50 \mathrm{~Hz}$ can be seen. However, when these transmission loss spectra are frequency-weighted by a detonation of $1.25 \mathrm{lb}$ of Composition C4, as indicated in Figure 10, those differences effectively disappear due to the very strong energy at $30 \mathrm{~Hz}$ and the rapidly decreasing energy as frequency increases. When these spectra are frequency-weighted by a rifle shot spectrum, as indicated in Figure 11, the characteristic "ground dip" is present near $225 \mathrm{~Hz}$, but the rest of the spectrum looks approximately like white noise. This spectrum is flat because the rifle spectrum has a large amount of energy near $500 \mathrm{~Hz}$, which corresponds well with the forest's scattering-induced attenuation. This scattering attenuation brings the levels up in that frequency range and effectively flattens out the spectrum.

\section{Time of Day and Time of Year - Spectral Analysis}

Changes in acoustic propagation due to time of year and time of day were examined for each stand age. Figures 12-16 show the unweighted spectra at each stand age. When examining the unweighted spectra, the most interesting finding is that, as the stand ages, the received levels vary less with time of year and time of day. Almost no temporal variation occurs in the 80-year stand, while variations of an average of $10 \mathrm{~dB}$ over all frequencies occur in the 10-year stand. One possible explanation for this finding is that, as the forest grows taller, the microclimate within becomes more stable due to the larger space that is minimally influenced by overall above-the-trees conditions. Acoustic propagation through a forest is inherently frequency-dependent. Most of the forest's influence on the received spectrum is in frequencies above $200 \mathrm{~Hz}$.

\section{Sound Exposure Levels}

Predictions were compared by looking at the SEL as a measure of the overall sound received. The SEL is calculated by summing the exposure in equally spaced frequency bands and expressing the results in decibels. SEL calculations were performed for the rifle and $1.25 \mathrm{lb}$ C4 weighted spectra, since the two sound sources have significantly different energy distributions. Tables 3 and 4 contain $\mathrm{C} 4$ weighted SEL values at the two distances examined in this study. At the shorter range $(174 \mathrm{~m})$, the 80 -year forest provides an additional 3 to $6 \mathrm{~dB}$ SEL. By the time 
the acoustic signal has traveled $900 \mathrm{~m}$, the levels in the 80 -year forest are actually 1 to $2 \mathrm{~dB}$ SEL higher. A 1 to $2 \mathrm{~dB}$ change is not significant, as a typical human ear cannot easily detect long-term changes of less than $3 \mathrm{~dB}$. Tables 5 and 6 contain rifle-weighted SEL values at the two distances examined in this study. At the shorter range $(174 \mathrm{~m})$, the 80 -year forest provides an additional 11 to $15 \mathrm{~dB}$ of attenuation over the 10-year old forest. At the longer range $(900 \mathrm{~m})$, this amount decreases to an additional 8 to $9 \mathrm{~dB}$ over the 10-year stand. This result indicates that a forest has a significant impact on received level of a higher-frequency-rich signal.

Table 5. Predicted received levels from $1.25 \mathrm{lb}$ C4 for the downwind condition, at $174 \mathrm{~m}$, red pine.

\begin{tabular}{|c|c|c|c|c|c|}
\hline $\begin{array}{c}\text { Age } \\
(\mathbf{y r})\end{array}$ & $\begin{array}{c}\text { Distance } \\
\mathbf{( m )}\end{array}$ & $\begin{array}{c}\text { Summer Day } \\
\text { dB SEL }\end{array}$ & $\begin{array}{c}\text { Summer Night } \\
\text { dB SEL }\end{array}$ & $\begin{array}{c}\text { Winter Day } \\
\text { dB SEL }\end{array}$ & $\begin{array}{c}\text { Winter Night } \\
\text { dB SEL }\end{array}$ \\
\hline 10 & 174 & 119.1 & 120.5 & 120.5 & 120.4 \\
\hline 20 & 174 & 118.7 & 120.0 & 119.8 & 120.4 \\
\hline 30 & 174 & 118.3 & 118.8 & 118.7 & 120.0 \\
\hline 40 & 174 & 117.3 & 117.3 & 117.3 & 117.7 \\
\hline 80 & 174 & 115.5 & 115.3 & 115.1 & 115.0 \\
\hline
\end{tabular}

Table 6. Predicted received levels from $1.25 \mathrm{lb}$ C4 for the downwind condition, at $900 \mathrm{~m}$, red pine.

\begin{tabular}{|c|c|c|c|c|c|}
\hline $\begin{array}{c}\text { Age } \\
(\mathbf{y r})\end{array}$ & $\begin{array}{c}\text { Distance } \\
(\mathbf{m})\end{array}$ & $\begin{array}{c}\text { Summer Day } \\
\mathbf{d B} \text { SEL }\end{array}$ & $\begin{array}{c}\text { Summer Night } \\
\mathbf{d B ~ S E L}\end{array}$ & $\begin{array}{c}\text { Winter Day } \\
\text { dB SEL }\end{array}$ & $\begin{array}{c}\text { Winter Night } \\
\text { dB SEL }\end{array}$ \\
\hline 10 & 900 & 119.7 & 122.6 & 122.6 & 121.5 \\
\hline 20 & 900 & 121.2 & 123.1 & 122.8 & 123.0 \\
\hline 30 & 900 & 121.9 & 123.3 & 123.0 & 123.7 \\
\hline 40 & 900 & 121.9 & 123.0 & 123.0 & 123.7 \\
\hline 80 & 900 & 122.1 & 123.8 & 123.5 & 122.7 \\
\hline
\end{tabular}

Table 7. Predicted received levels from rifle shot for the downwind condition, at $174 \mathrm{~m}$, red pine.

\begin{tabular}{|c|c|c|c|c|c|}
\hline $\begin{array}{c}\text { Age } \\
(\mathbf{y r})\end{array}$ & $\begin{array}{c}\text { Distance } \\
(\mathbf{m})\end{array}$ & $\begin{array}{c}\text { Summer Day } \\
\text { dB SEL }\end{array}$ & $\begin{array}{c}\text { Summer Night } \\
\text { dB SEL }\end{array}$ & $\begin{array}{c}\text { Winter Day } \\
\text { dB SEL }\end{array}$ & $\begin{array}{c}\text { Winter Night } \\
\text { dB SEL }\end{array}$ \\
\hline 10 & 174 & 84.6 & 84.2 & 84.1 & 80.7 \\
\hline 20 & 174 & 76.8 & 77.3 & 76.4 & 62.8 \\
\hline 30 & 174 & 63.5 & 63.7 & 63.7 & 65.9 \\
\hline 40 & 174 & 63.8 & 63.0 & 63.0 & 62.8 \\
\hline 80 & 174 & 69.7 & 69.7 & 69.4 & 68.9 \\
\hline
\end{tabular}


Table 8. Predicted received levels from rifle shot for the downwind condition, at $900 \mathrm{~m}$, red pine.

\begin{tabular}{|c|c|c|c|c|c|}
\hline $\begin{array}{c}\text { Age } \\
(\mathbf{y r})\end{array}$ & $\begin{array}{c}\text { Distance } \\
(\mathbf{m})\end{array}$ & $\begin{array}{c}\text { Summer Day } \\
\text { dB SEL }\end{array}$ & $\begin{array}{c}\text { Summer Night } \\
\text { dB SEL }\end{array}$ & $\begin{array}{c}\text { Winter Day } \\
\text { dB SEL }\end{array}$ & $\begin{array}{c}\text { Winter Night } \\
\text { dB SEL }\end{array}$ \\
\hline 10 & 900 & 71.6 & 76.5 & 77.4 & 77.1 \\
\hline 20 & 900 & 69.0 & 75.9 & 74.5 & 76.1 \\
\hline 30 & 900 & 61.6 & 68.7 & 67.8 & 73.4 \\
\hline 40 & 900 & 61.3 & 67.0 & 66.9 & 70.4 \\
\hline 80 & 900 & 63.9 & 67.7 & 68.1 & 69.7 \\
\hline
\end{tabular}
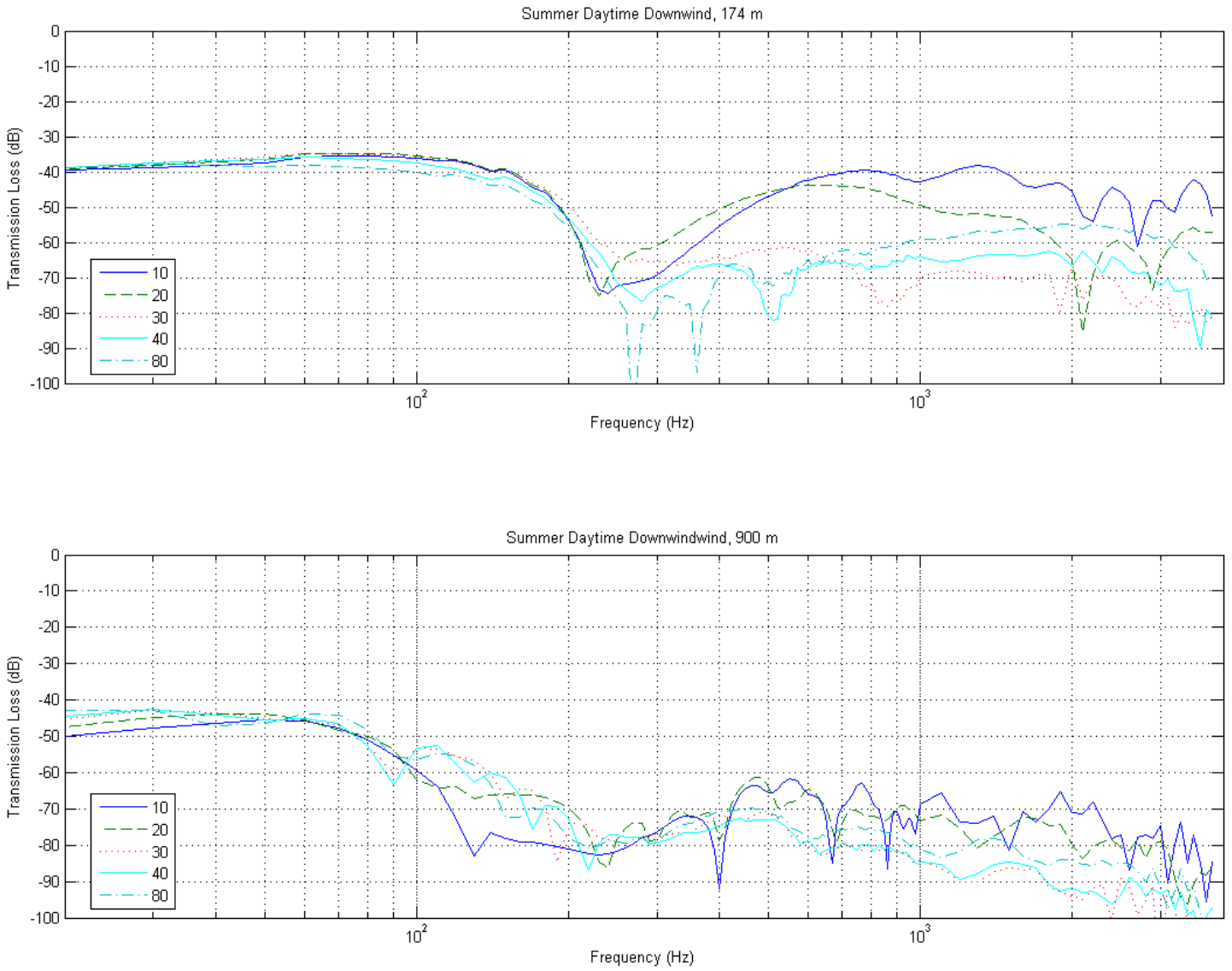

Figure 2. Summer Daytime downwind cases, all forest stand ages, transmission loss of unweighted levels. 

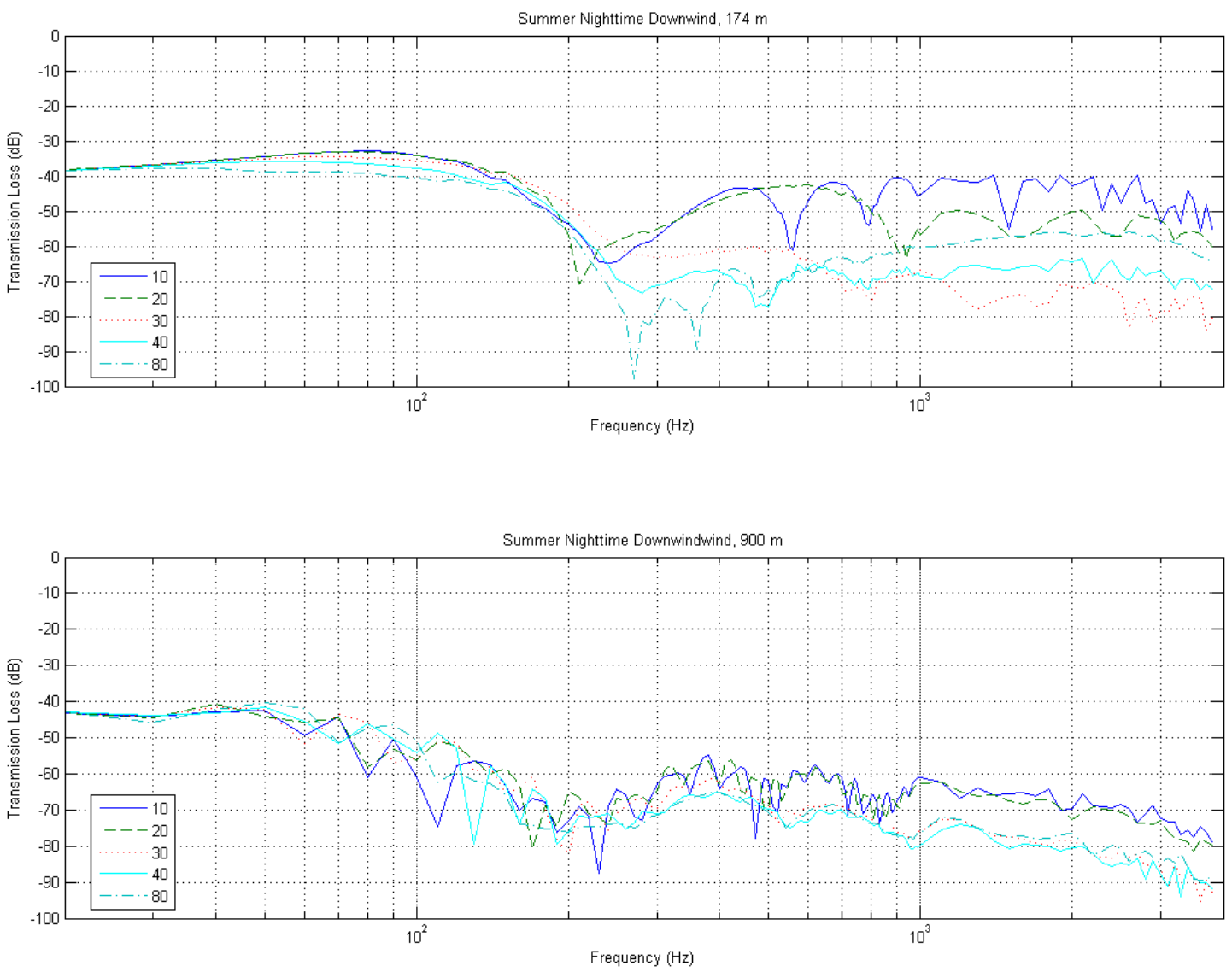

Figure 3. Summer Nighttime downwind cases, all forest stand ages, transmission loss of unweighted levels. 

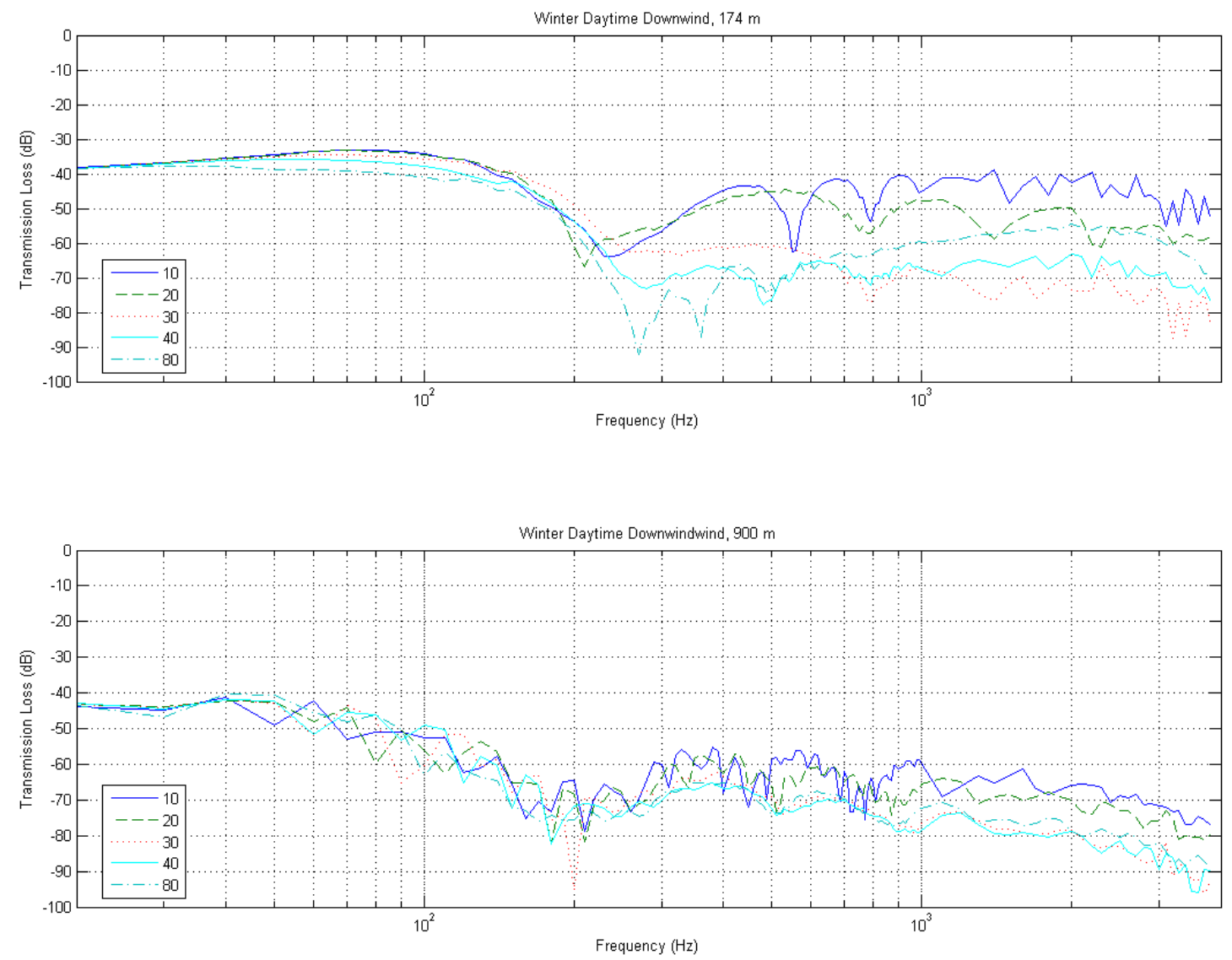

Figure 4. Winter Daytime downwind cases, all forest stand ages, transmission loss of unweighted levels. 

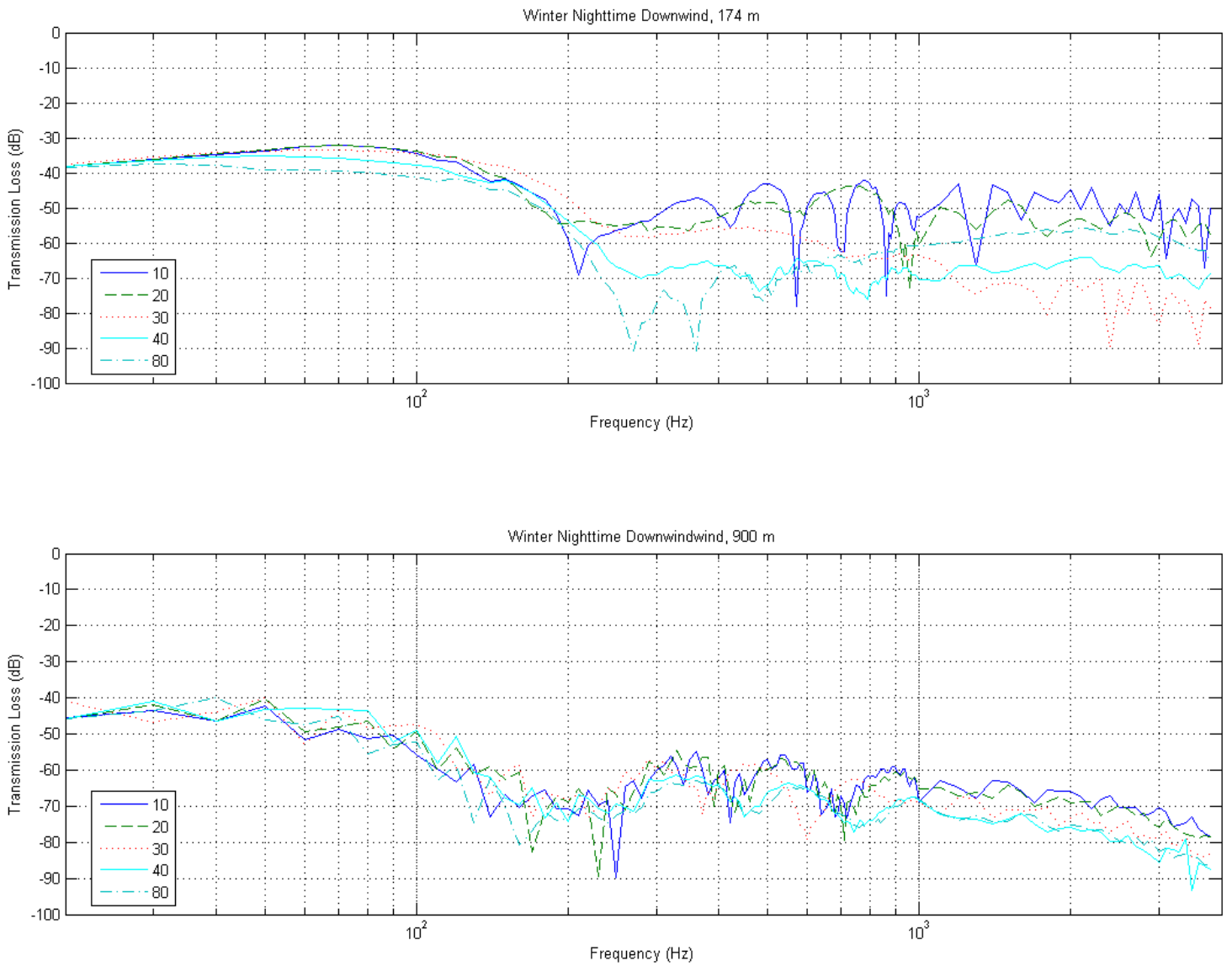

Figure 5. Winter Nighttime downwind cases, all forest stand ages, transmission loss of unweighted levels. 

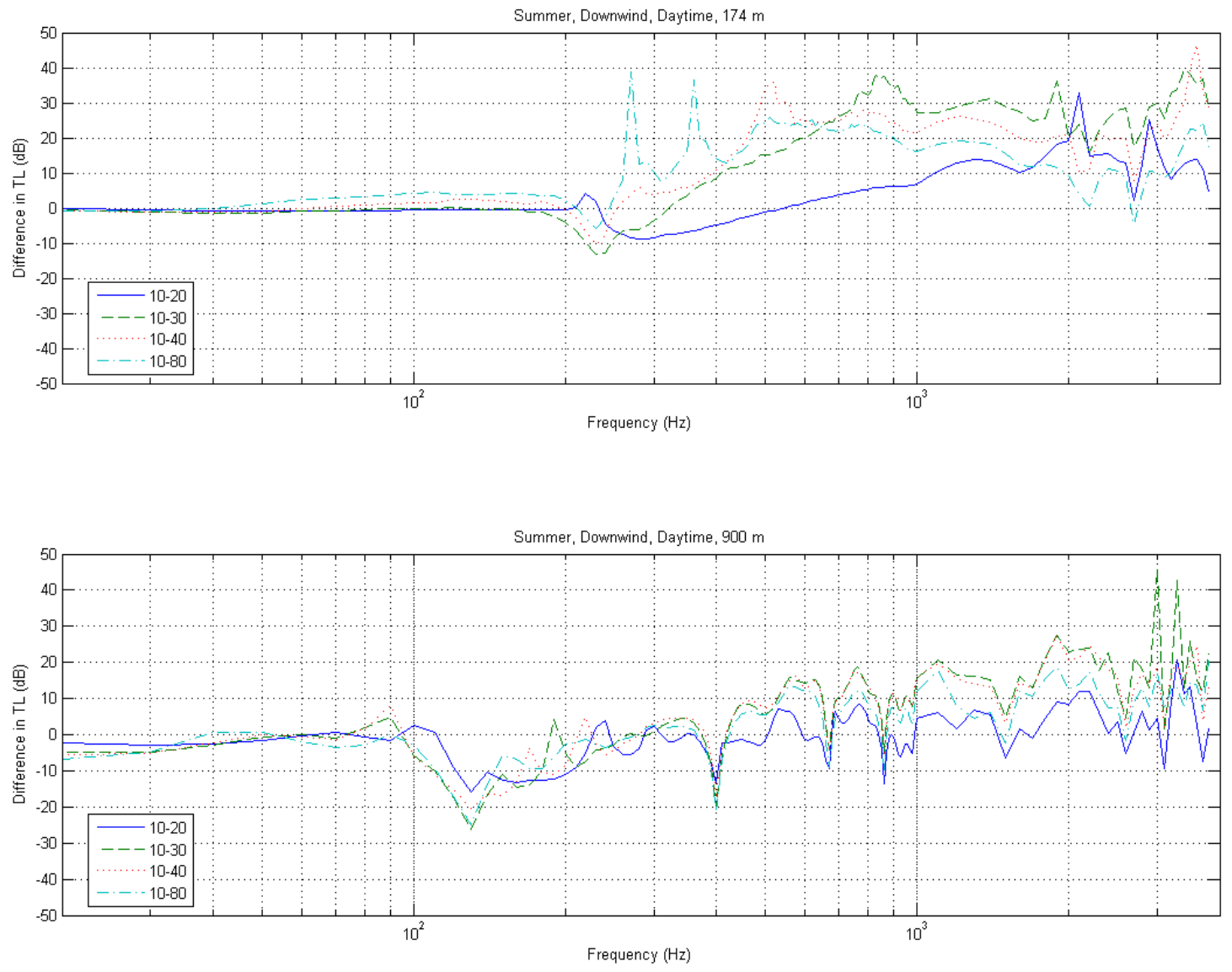

Figure 6. Summer Daytime downwind case, difference in transmission loss between 10-year stand and all other ages. 

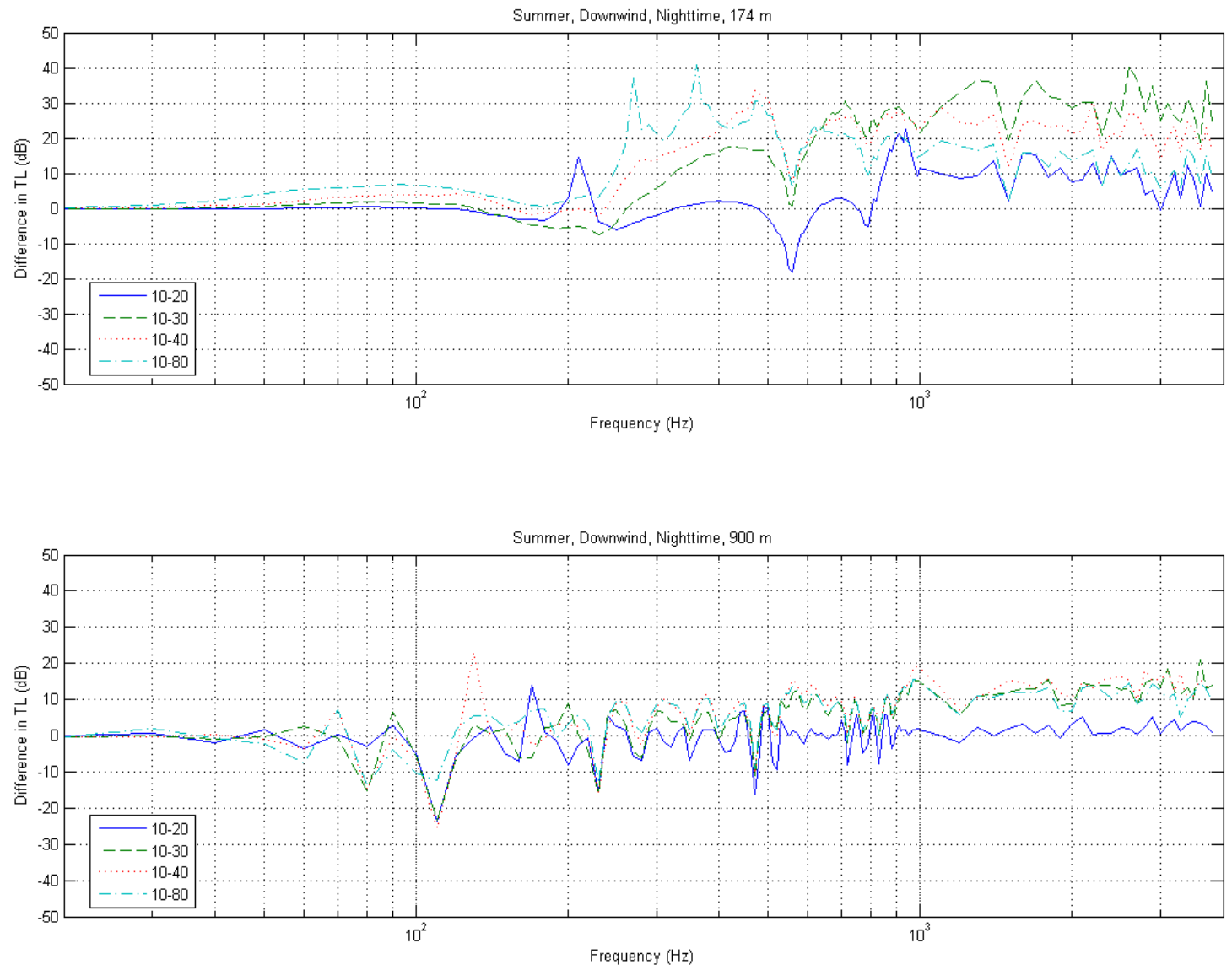

Figure 7. Summer Nighttime downwind case, difference in transmission loss between 10-year stand and all other ages. 

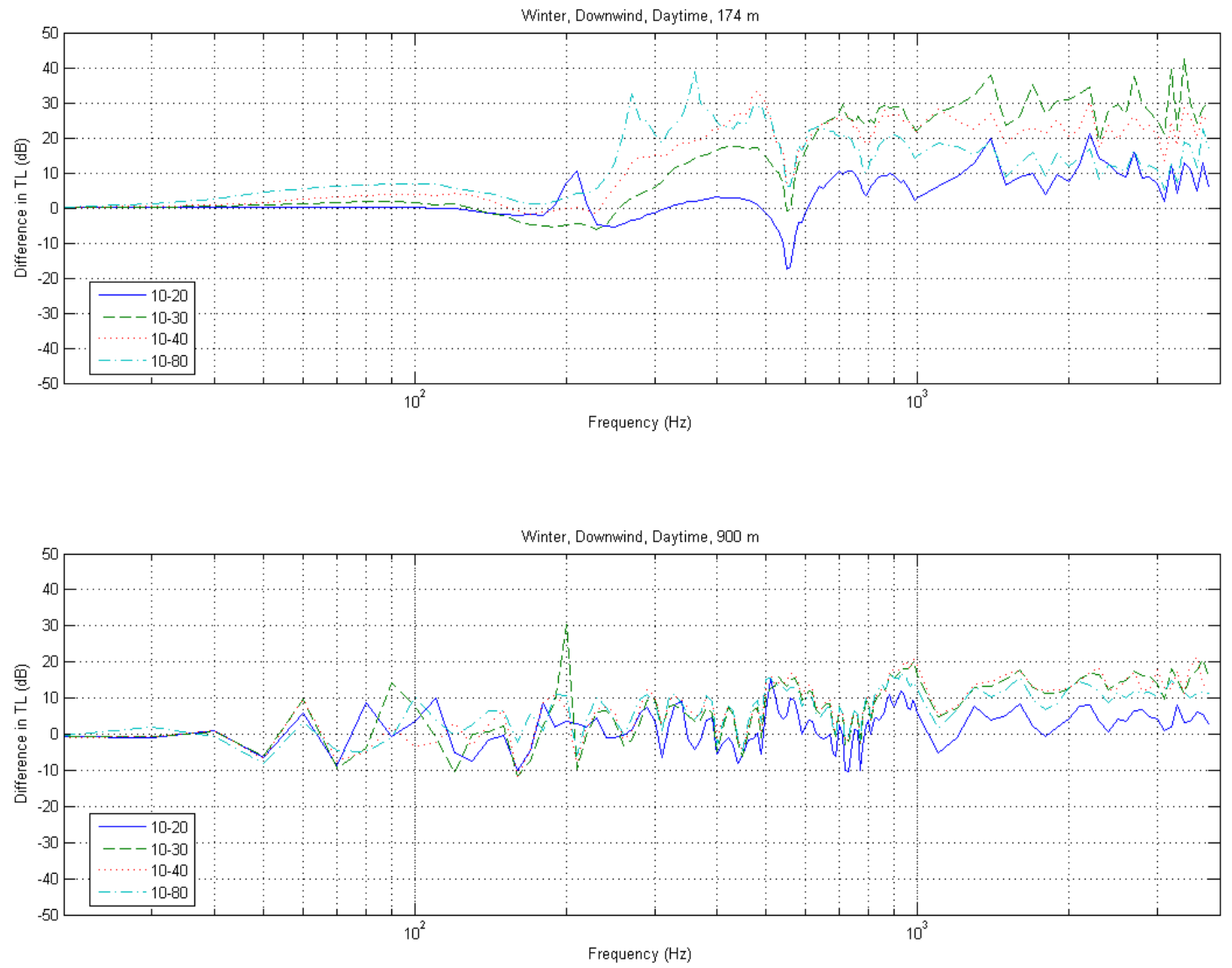

Figure 8. Winter Daytime downwind case, difference in transmission loss between 10-year stand and all other ages. 

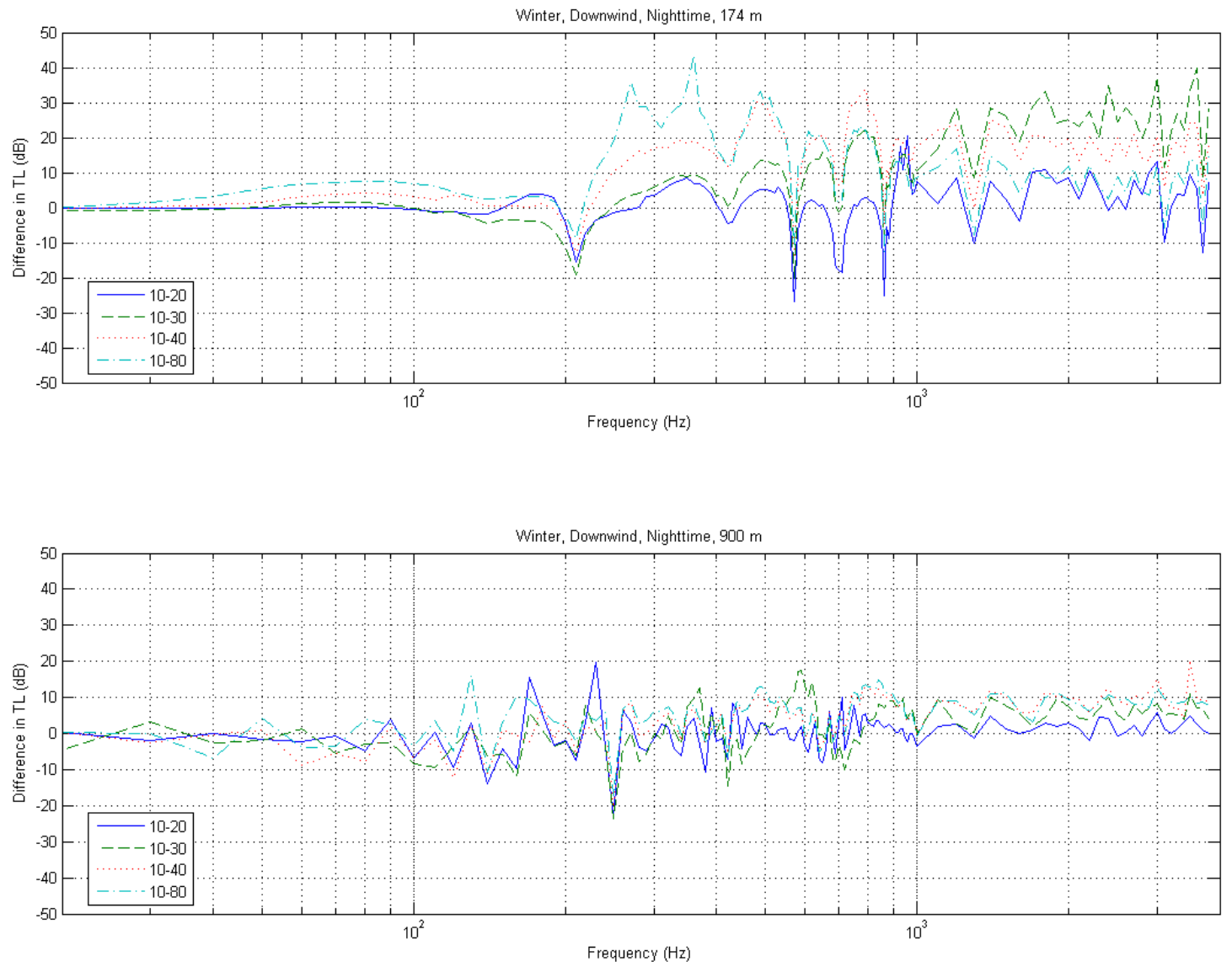

Figure 9. Winter Nighttime downwind case, difference in transmission loss between 10-year stand and all other ages. 

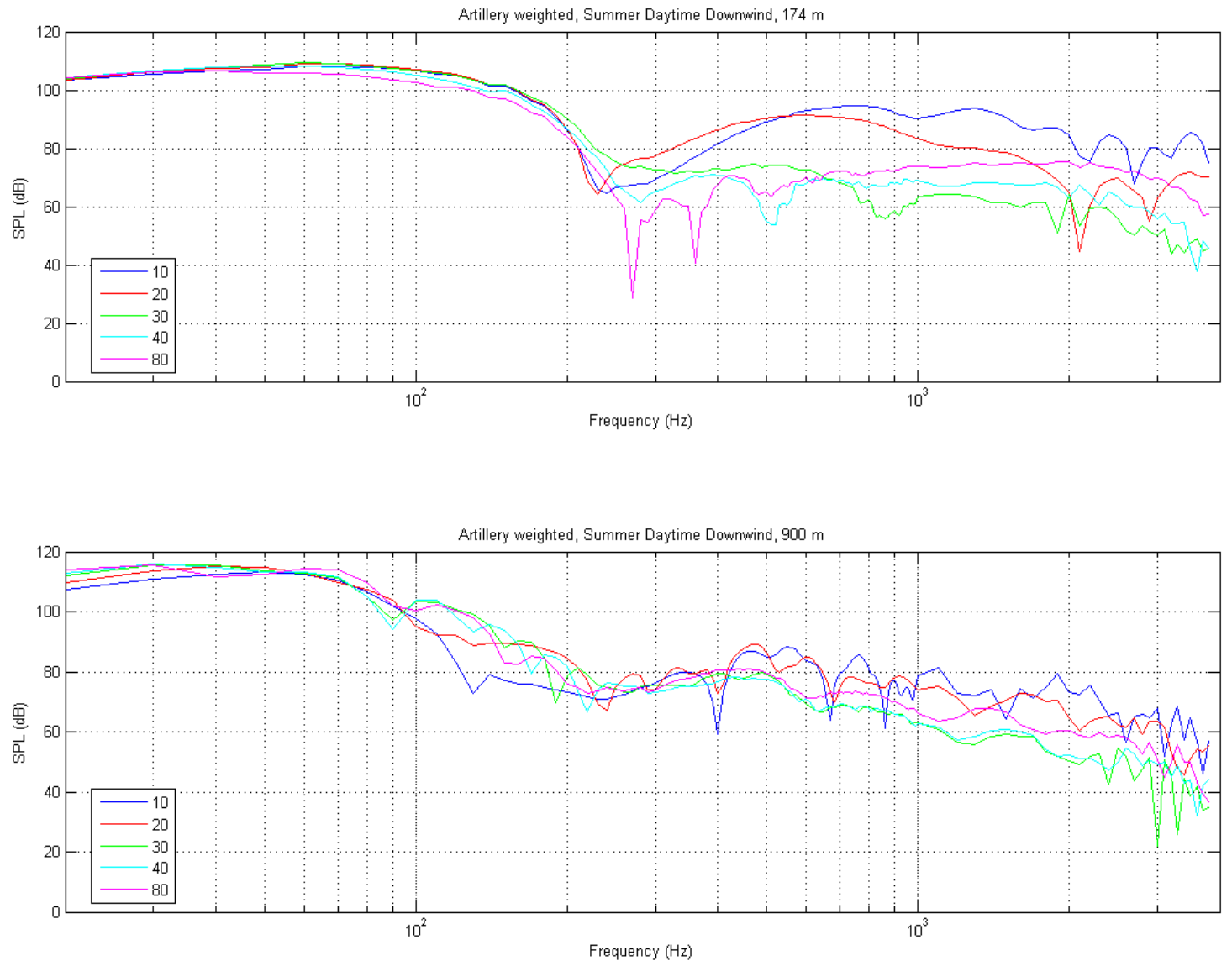

Figure 10. Spectra weighted with 1.25 lb C4 spectrum. Summer Daytime case, all stand ages. Summer daytime chosen as a representative sample. 

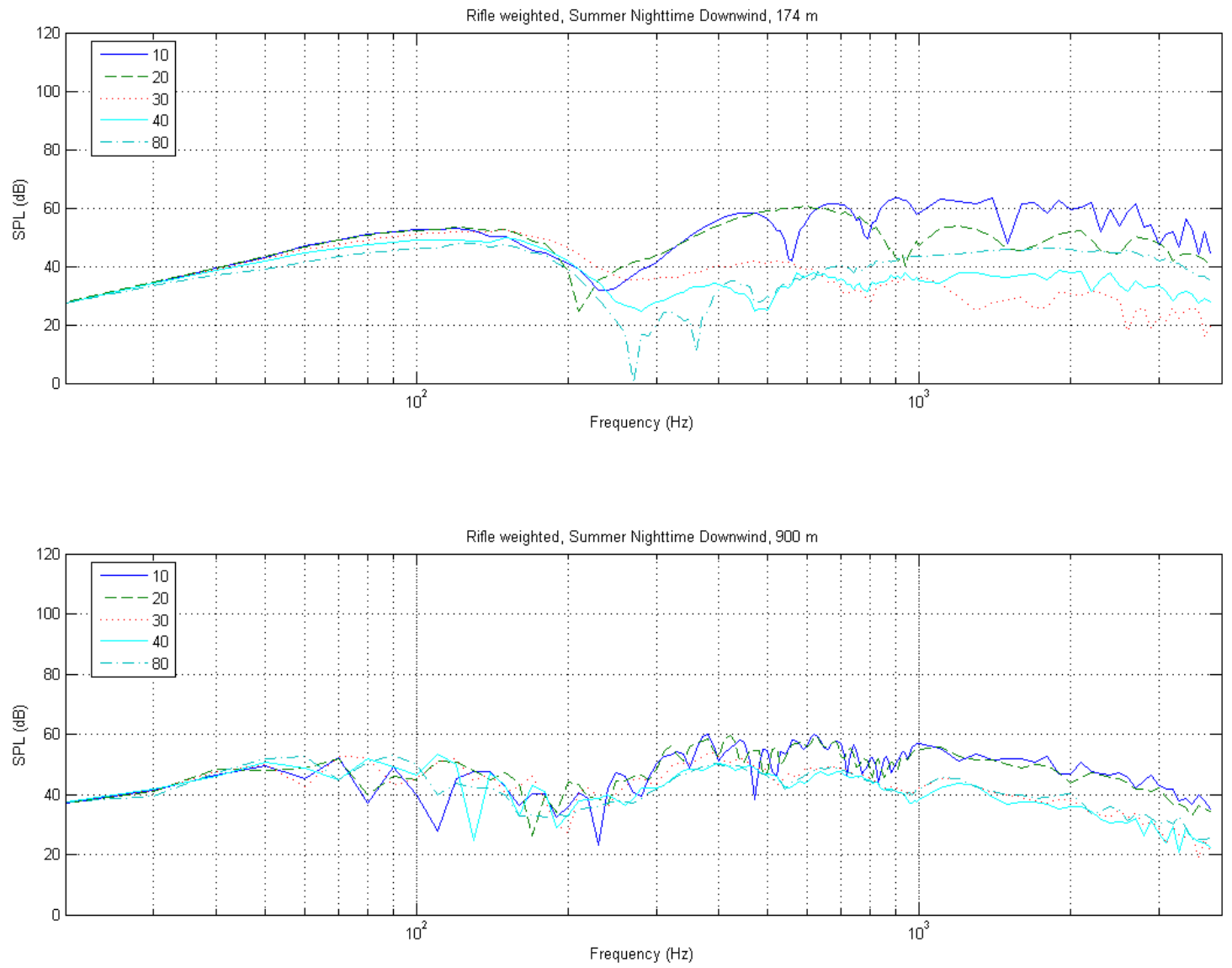

Figure 11. Spectra weighted with rifle spectrum. Summer Nighttime case, all stand ages. Summer nighttime chosen as a representative sample. 

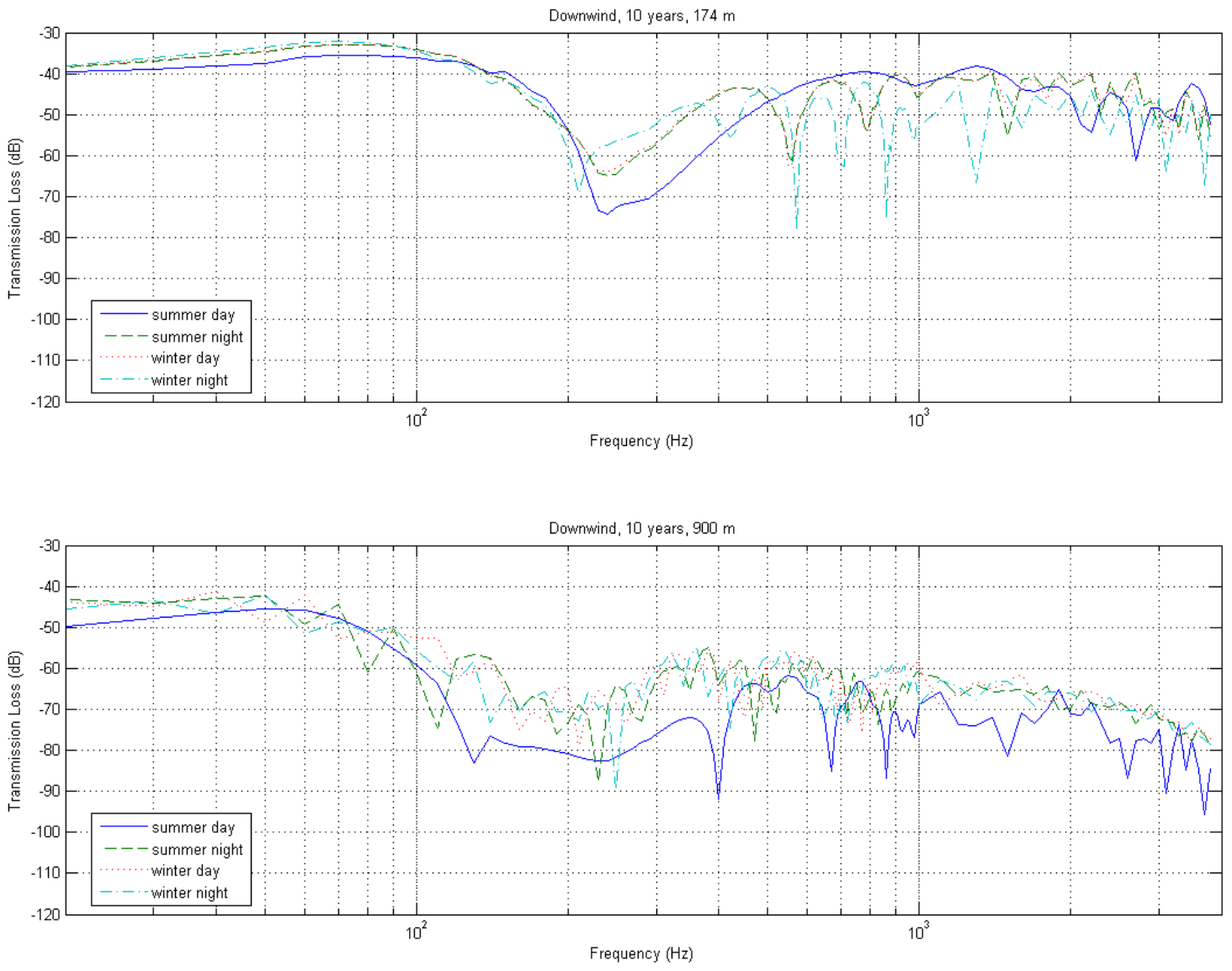

Figure 12. Unweighted spectrum of 10-year red pine stand for all temporal conditions, downwind case. 

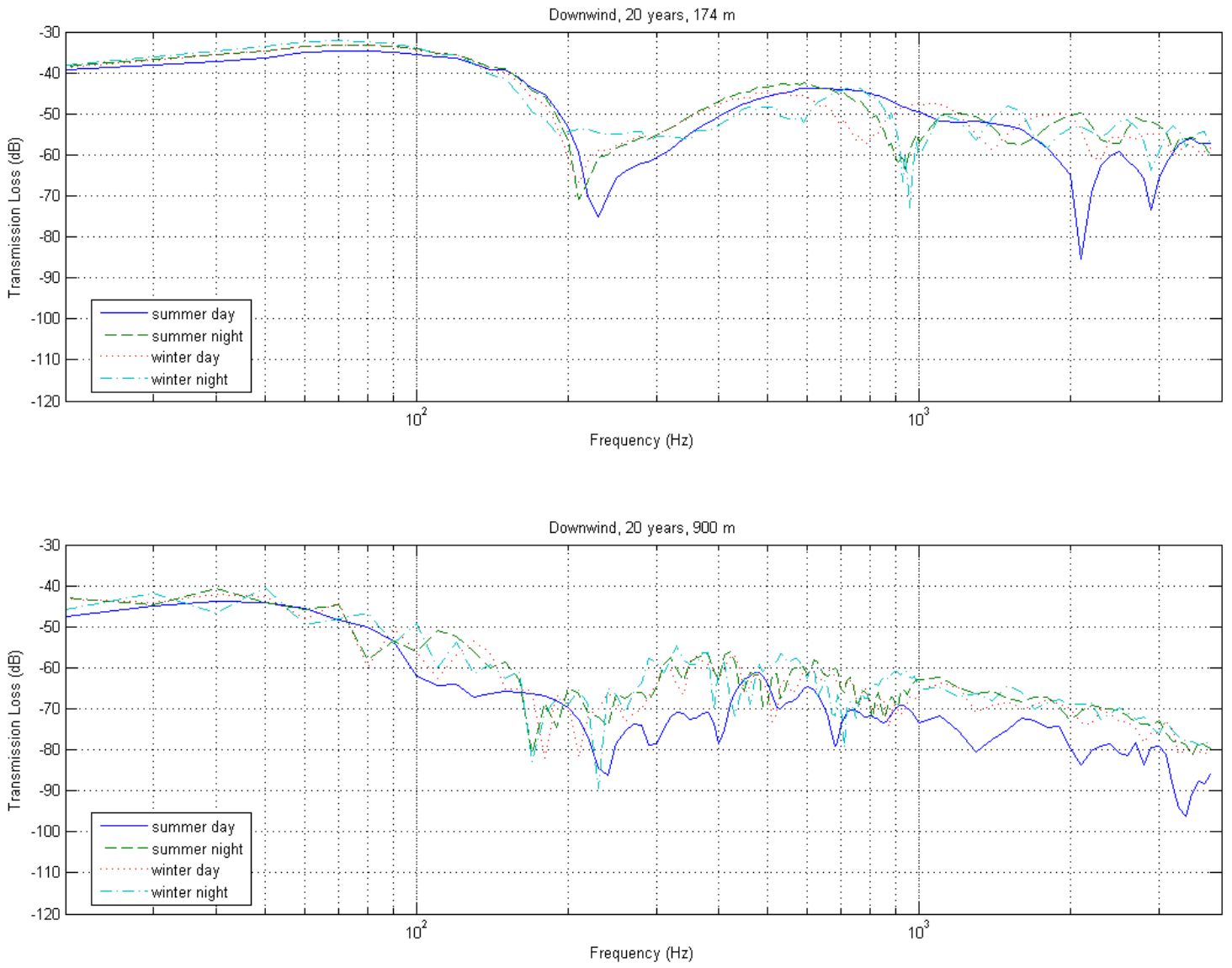

Figure 13. Unweighted spectrum of 20-year red pine stand for all temporal conditions, downwind case. 

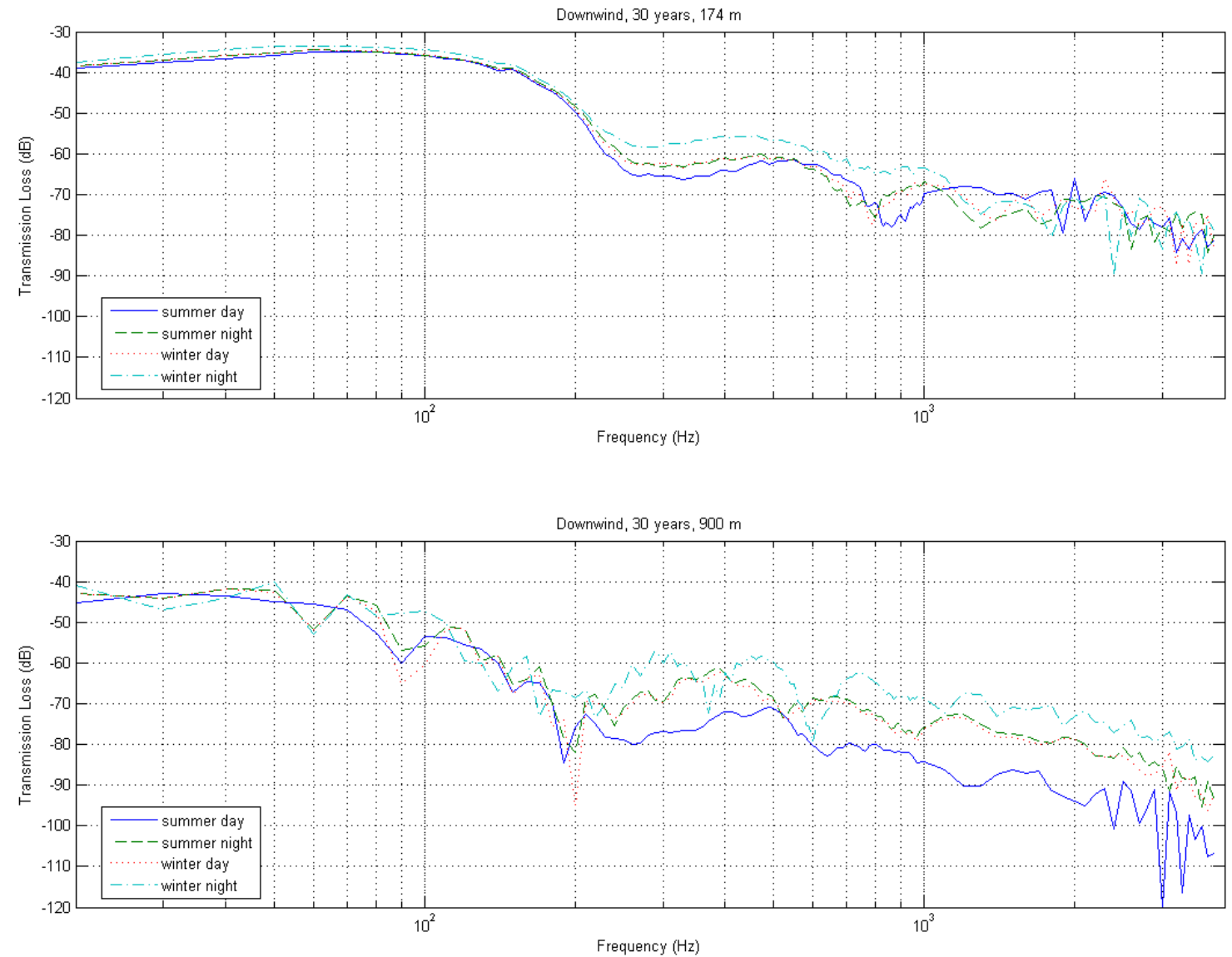

Figure 14. Unweighted spectrum of 30-year red pine stand for all temporal conditions, downwind case. 

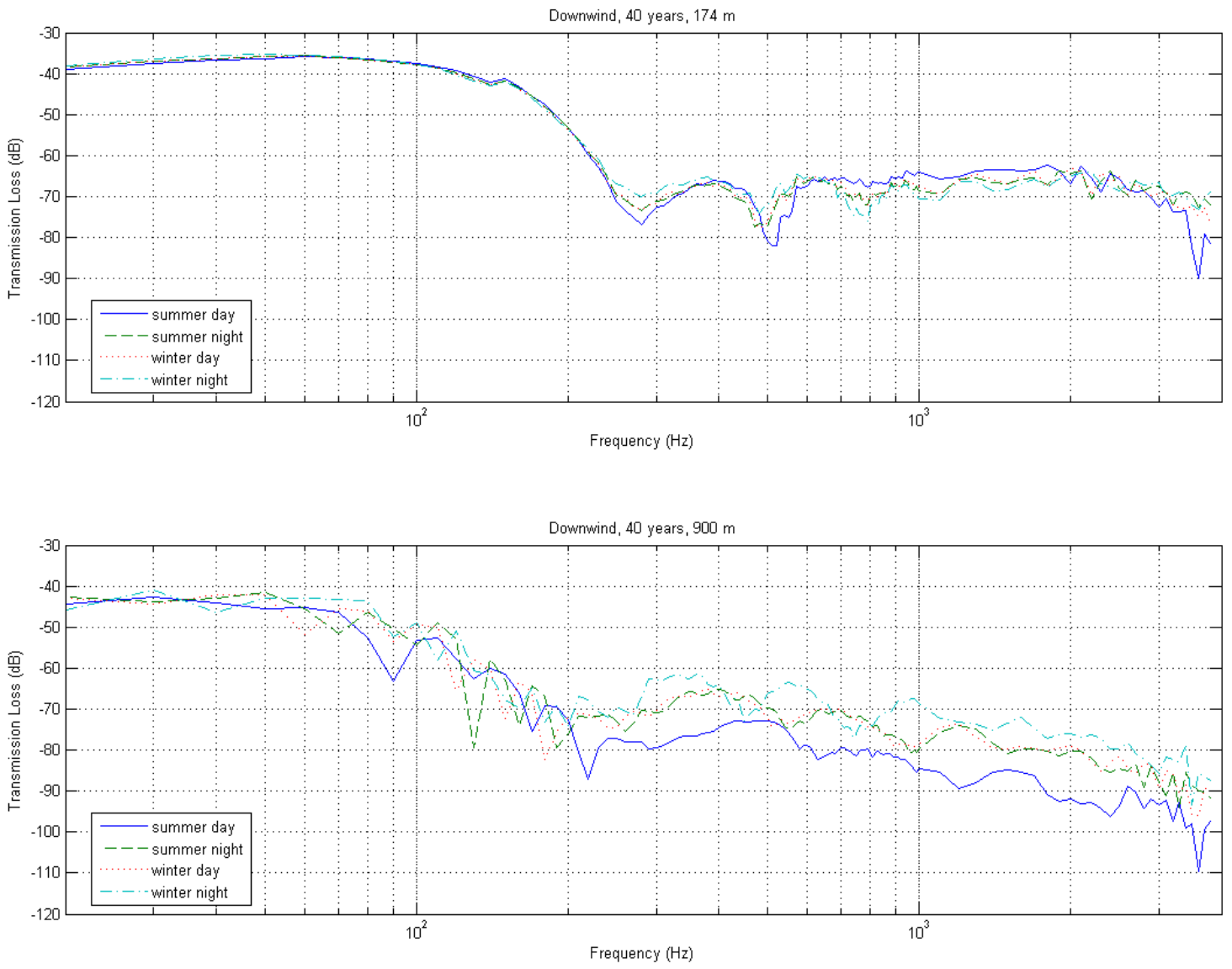

Figure 15. Unweighted spectrum of 40 -year red pine stand for all temporal conditions, downwind case. 

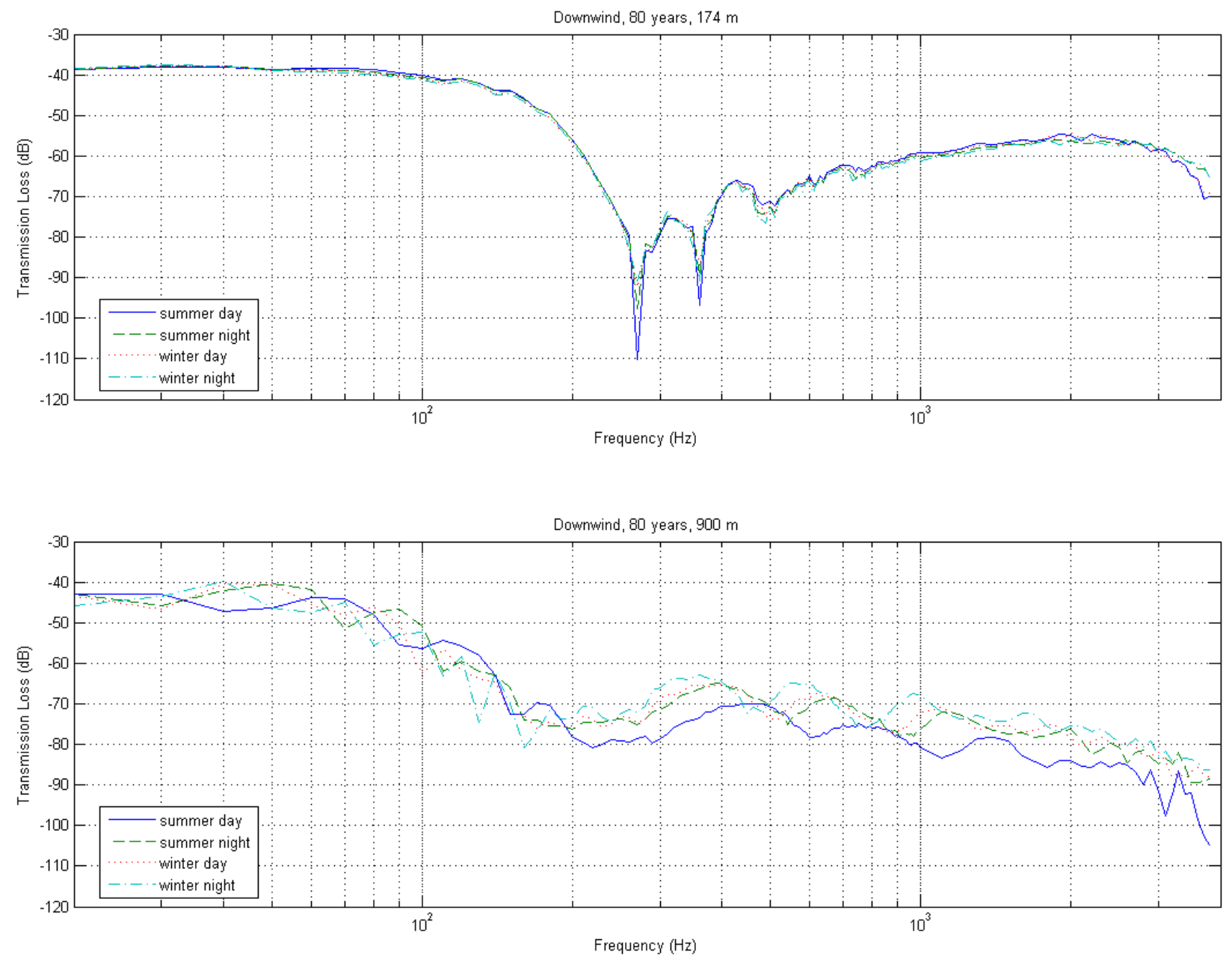

Figure 16. Unweighted spectrum of 80-year red pine stand for all temporal conditions, downwind case. 


\section{Conclusions and Recommendations}

\section{Conclusions}

Several conclusions can be drawn from this study. The examination of sound attenuation indicates that, as the stand ages, the frequency at which the forest has a significant mitigation benefit changes. However, when the spectra are weighted with a demolition source spectrum, the mitigation benefits are minimized. When applied to the rifle source spectrum, the spectra begin to look like white noise. The examination of sound propagation in the red pine indicates that, as the forest ages, the propagation within the forest becomes more stable across weather conditions. Coherent field sound exposure analysis indicates that the forest age and structure has little effect on blast noise. It is important to note here that this theoretical study does not include the contribution of a forest edge, which has an unknown effect on low-frequency sound. The coherent energy sound exposure analysis indicates that, for small arms noise such as a rifle shot, the age of the stand is a significant factor in the amount of attenuation the forest produces.

Because this study did not compare open field propagation to forest propagation, the overall impact of a forest on sound propagation compared to open field propagation is not discussed here. The results of this study indicate that an older forest will produce a larger noise mitigation impact for small arms fire. However, the age of the stand and corresponding size of the trees has negligible impact on noise mitigation for large weapons (e.g., such as artillery and armor) or demolitions.

\section{Recommendations}

This study has shown the importance of considering the long-term growth of forest when evaluating their noise mitigation benefit. However, it does not give any general insight into how much forest and in what configuration will give optimal sound attenuation. The forest edge remains an unknown factor in the equation, so the influence of a band of trees, for example, is not fully understood. Future work should include a detailed study of the forest edge effect and a set of generalized recommendations for use of forests to mitigate training and testing noise. 


\section{References}

American National Standards Institute (ANSI). 1983. Estimating air blast characteristics for single point explosions in air, with a guide to evaluation of atmospheric propagation and effects. ANSI S2.20-1983.

Daigle, G.A., J.E. Piercy, and T.F.W. Embleton. 1978. Effects of atmospheric turbulence on the interference of sound waves near a hard boundary, J. Acoust. Soc. Am. 64(2):622-630.

Friedlander, F.G. 1946. The diffraction of sound pulses, Proc. R. Soc. London. Ser. A:322-367.

Swearingen, M.E., and M.J. White. 2004. Effects of forests on blast noise. ERDC/CERL TR-05-29. Champaign, IL:U.S. Army Engineer Research and Development Center.

Tunick, A. 2003. Calculating the micrometeorological influences on the speed of sound through the atmosphere in forests. J. Acoust. Soc. Am. 114(4):1796-1806.

Twersky, V. 1962. On scattering of waves by random distributions I. free-space scatter formalism. J. Math. Physics. 3(4):700-715.

White, M.J., and M.E. Swearingen. 2004. Sound propagation through a forest: a predictive model. MP-04-3, Champaign, IL:U.S. Army Engineer Research and Development Center. 


\section{Appendix: Sound Propagation Modeling Results for Slash Pine Data}

This appendix fully describes the previous sound propagation modeling results performed on existing stand data. In this previous exercise, an existing configuration of slash pine was grown at a fixed percentage rate for 20 years. The Forest Green Function Parabolic Equation (GFPE) was run for both the initial and final states. Additionally, the existing configuration was modified such that 60 percent of the trees were removed and then grown at the same fixed percentage rates for 20 years. Again, the Forest GFPE was run for both initial and final states. The initial states and final states were all compared with each other. Figure A1 shows this comparison of frequency spectra weighted by a $1.25-\mathrm{lb}(0.567 \mathrm{~kg})$ charge of Composition C4 for the downwind case. As with the main portion of this study, the shadow zone effect was judged to be too strong, so only the downwind cases are examined. By looking at this figure, it is immediately apparent that for low frequencies $(<100 \mathrm{~Hz})$, the number of trees in the stand does not matter. For higher frequencies such as from a rifle shot, however, the structure of the forest has a significant effect. At $900 \mathrm{~m}$ from the source, the configuration with all of the trees aged 20 years provides approximately $5 \mathrm{~dB}$ more attenuation, on average, above $200 \mathrm{~Hz}$ over the thinned and aged configuration.

A second way to look at the information is to use a sound exposure level (SEL), in which all of the coherent field sound exposure in equally sized frequency bands is summed. This way looks at the overall level of the received signal. Table 5 shows the SEL $(\mathrm{dB})$ for rifle shot source-weighted spectra. Clearly, the forest structure has an impact on the propagation when there is relatively more energy in the 500 $\mathrm{Hz}$ range. The SEL values indicate a $6 \mathrm{~dB}$ increase in received level at $900 \mathrm{~m}$ when 60 percent of the forest is initially thinned. After 20 years of growth for each situation, the thinned forest is providing $7 \mathrm{~dB}$ less attenuation.

When the transmission loss spectra are weighted with a source spectrum for a 1.25-lb charge of $\mathrm{C} 4$, a relatively large amount of the source sound exposure is present below $100 \mathrm{~Hz}$. Correspondingly, the SEL values vary only slightly, as is expected when one references Figure A1. 

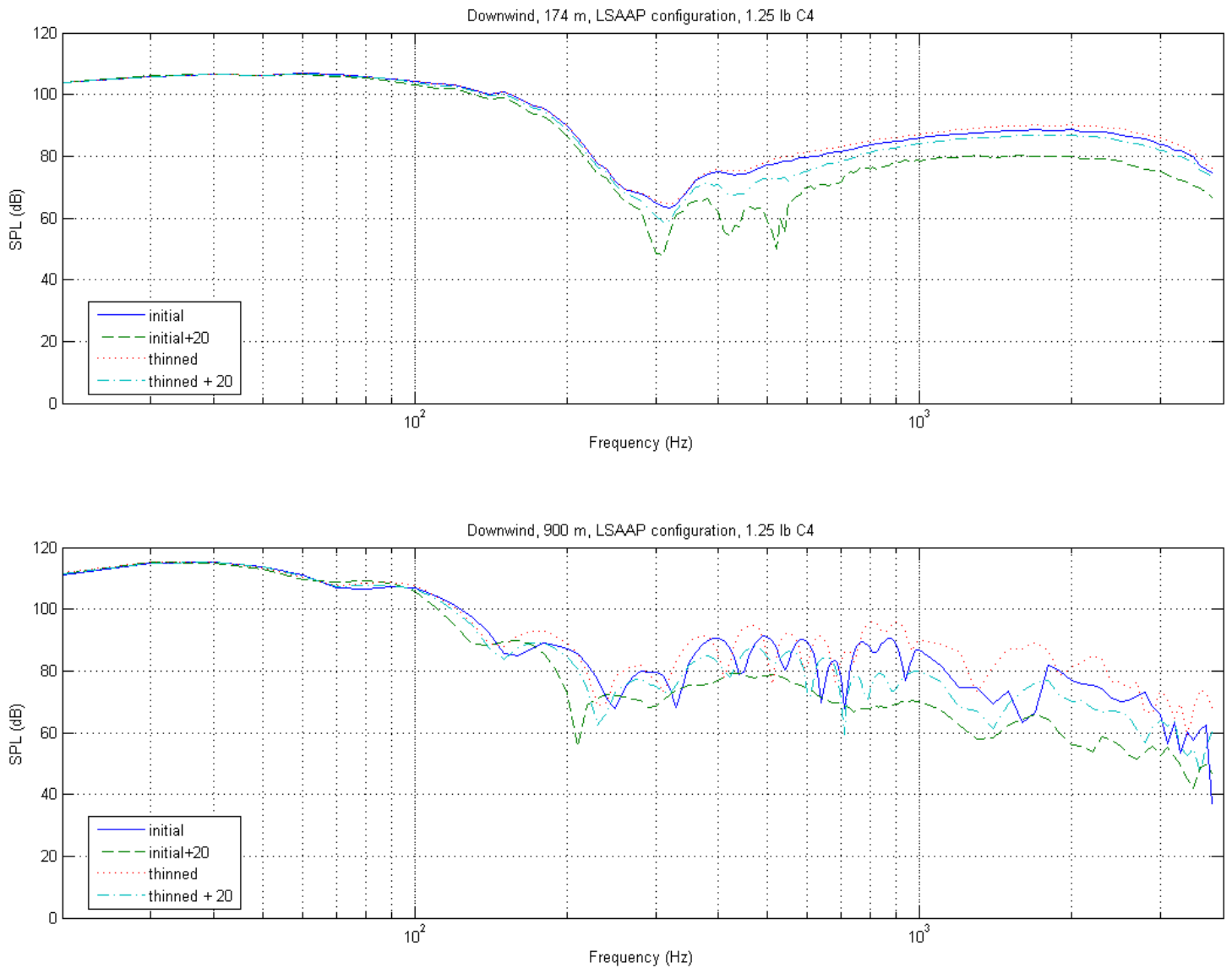

Figure A1. Calculated spectrum weighted with $1.25 \mathrm{lb}$ Composition C4 signature, slash pine forest.

To summarize the results, thinning this slash pine forest had negligible impact for low frequency-rich sounds, such as artillery or demolitions. If the forest were intended to mitigate small arms fire noise, thinning would not be recommended. One caveat here is that the forest edge effect has not been taken into account. This study assumes that the source and receiver are both within the forest. A second caveat is that the computational model only takes the coherent energy into account. As noted earlier in this report, the incoherent energy propagates in all directions and produces the reverberant field. 
Table A1. Predicted received levels from rifle shot for the downwind condition, slash pine.

\begin{tabular}{|c|c|c|c|c|}
\hline $\begin{array}{c}\text { Distance } \\
(\mathbf{m})\end{array}$ & $\begin{array}{c}\text { Initial Config. } \\
\text { dB SEL }\end{array}$ & $\begin{array}{c}\text { Initial + 20 years } \\
\text { dB SEL }\end{array}$ & $\begin{array}{c}\mathbf{6 0 \%} \text { Thinned } \\
\text { dB SEL }\end{array}$ & $\begin{array}{c}\text { 60\% Thinned + 20 years } \\
\text { dB SEL }\end{array}$ \\
\hline 174 & 83.0 & 74.7 & 84.6 & 81.2 \\
\hline 900 & 75.7 & 62.8 & 81.8 & 70.2 \\
\hline
\end{tabular}

Table A2. Predicted received levels from $1.25 \mathrm{lb}$ C4 for the downwind condition, slash pine.

\begin{tabular}{|c|c|c|c|c|}
\hline $\begin{array}{c}\text { Distance } \\
(\mathbf{m})\end{array}$ & $\begin{array}{c}\text { Initial Config. } \\
\text { dB SEL }\end{array}$ & $\begin{array}{c}\text { Initial + 20 years } \\
\text { dB SEL }\end{array}$ & $\begin{array}{c}\mathbf{6 0 \%} \text { Thinned } \\
\text { dB SEL }\end{array}$ & $\begin{array}{c}\mathbf{6 0 \%} \text { Thinned + 20 years } \\
\text { dB SEL }\end{array}$ \\
\hline 174 & 117.5 & 116.1 & 117.9 & 117.0 \\
\hline 900 & 121.5 & 121.3 & 122.0 & 121.4 \\
\hline
\end{tabular}




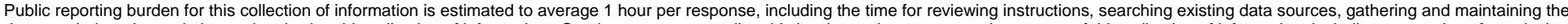

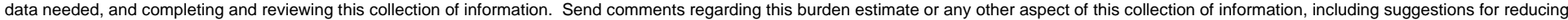

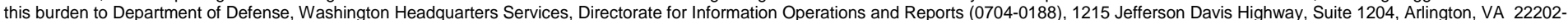

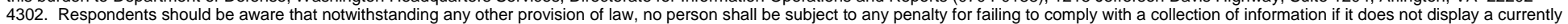
valid OMB control number. PLEASE DO NOT RETURN YOUR FORM TO THE ABOVE ADDRESS

\section{REPORT DATE (DD-MM-YYYY) 03-2006}

4. TITLE AND SUBTITLE

Effect of Age-dependent Forest Characteristics on Acoustic Propagation
3. DATES COVERED (From - To)

5a. CONTRACT NUMBER

5b. GRANT NUMBER

5c. PROGRAM ELEMENT NUMBER

5d. PROJECT NUMBER

$622720 \mathrm{D} 048$

5e. TASK NUMBER

5f. WORK UNIT NUMBER

3JD946

8. PERFORMING ORGANIZATION REPORT NUMBER

ERDC/CERL TR-06-4

U.S. Army Engineer Research and Development Center (ERDC)

Construction Engineering Research Laboratory (CERL)

PO Box 9005

Champaign, IL 61826-9005

\section{SPONSORING I MONITORING AGENCY NAME(S) AND ADDRESS(ES)}

U.S. Army Center for Health Promotion and

Preventive Medicine

5158 Blackhawk Road

Aberdeen Proving Ground, MD 21010-5403

10. SPONSOR/MONITOR'S ACRONYM(S)

MCHB-TS-EEN

11. SPONSOR/MONITOR'S REPORT NUMBER(S)

\section{DISTRIBUTION / AVAILABILITY STATEMENT}

Approved for public release; distribution is unlimited.

\section{SUPPLEMENTARY NOTES}

Copies are available from the National Technical Information Service, 5285 Port Royal Road, Springfield, VA 22161.

\section{ABSTRACT}

This report contains the results of a theoretical study on the impact of forest stand age on acoustic propagation. A red pine forest was simulated at 10, 20, 30, 40, and 80 years of age, with assumptions that it was being maintained for utility pole harvest. Forest parameters, such as density, height, and diameter of trees, were used to predict vertical sound speed profiles and then acoustic propagation. The resulting spectra were weighted to simulate artillery and rifle fire. Spectra and sound exposure levels were examined to determine whether the forest stand age has a significant impact on acoustic propagation within a forest.

\section{SUBJECT TERMS}

environmental planning

military training noise mitigation

land use planning

\begin{tabular}{|c|c|c|c|c|}
\hline \multicolumn{3}{|c|}{ 16. SECURITY CLASSIFICATION OF: } & \multirow{2}{*}{$\begin{array}{l}\text { 17. LIMITATION } \\
\text { OF ABSTRACT } \\
\text { SAR }\end{array}$} & \multirow{2}{*}{$\begin{array}{l}\text { 18. NUMBER } \\
\text { OF PAGES } \\
41\end{array}$} \\
\hline $\begin{array}{l}\text { a. REPORT } \\
\text { Unclassified }\end{array}$ & $\begin{array}{l}\text { b. ABSTRACT } \\
\text { Unclassified }\end{array}$ & $\begin{array}{l}\text { c. THIS PAGE } \\
\text { Unclassified }\end{array}$ & & \\
\hline
\end{tabular}

low-frequency noise

19a. NAME OF RESPONSIBLE PERSON Michelle E. Swearingen

19b. TELEPHONE NUMBER (include area code) 217-373-4521 